\title{
Prospects for improving perennial legume persistence in mixed grazed pastures of south-eastern Australia, with particular reference to white clover
}

\author{
R. C. Hayes ${ }^{\mathrm{D}}$, I. Ara ${ }^{\mathrm{D}}$ B, W. B. Badgery ${ }^{\mathrm{C}}$, R. A. Culvenor ${ }^{\mathrm{D}}$, R. E. Haling ${ }^{\mathrm{D}}$, C. A. Harris $^{\mathrm{E}}$,

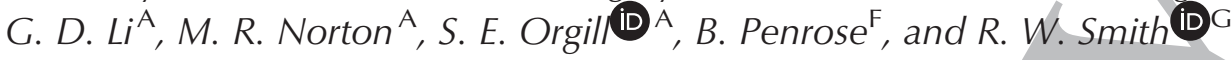 \\ ANW Department of Primary Industries, Wagga Wagga Agricultural Institute, Pine Gully Road, Wagga Wagga, \\ NSW 2650, Australia. \\ ${ }^{B}$ Tasmanian Institute of Agriculture, University of Tasmania, Private Bag 3523, Burnie, Tas. 7320, Australia. \\ C NSW Department of Primary Industries, Orange Agricultural Institute, Forest Road, Orange, NSW 2800, Australia. \\ ${ }^{D}$ CSIRO Agriculture, GPO 1700, Canberra, ACT 2601, Australia. \\ ENSW Department of Primary Industries, Glen Innes Agricultural Institute, PMB, Glen Innes, NSW 2370, Australia. \\ ${ }^{\mathrm{F}}$ Tasmanian Institute of Agriculture, University of Tasmania, Private Bag 98, Hobart, Tas. 7001, Australia. \\ GTasmanian Institute of Agriculture, University of Tasmania, Private Bag 1375, Launceston, Tas. 7250, Australia. \\ Corresponding author. Email: richard.hayes@dpi.nsw.gov.au
}

\begin{abstract}
This review examines the prospect of improving perennial legume adaptation to grazed mixed pasture swards across the higher-altitude regions of south-eastern Australia through improved management, particularly as it relates to soil fertility. The range of adapted perennial species available to farmers often remains limited to only one perennial forage legume species, white clover (Trifolium repens L.). Despite recent advances in cultivars for increased persistence in dryland environments, white clover remains sensitive to drought with its inherently shallow root system and limited capacity to restrict water loss from herbage. With few alternative species likely to become widely available in the foreseeable future, prospects for extending the boundaries of perennial legume adaptation likely rely on a dual approach of improving soil fertility and further genetic improvement in white clover. Improved soil fertility would focus on overcoming soil acidity and addressing nutrient deficiencies, particularly of phosphorus, potassium, boron and molybdenum, which tend to be more widespread in the target region. Addressing these soil constraints would alleviate periodic moisture stress by: (1) increased water availability through improved infiltration and soil hydraulic properties; (2) increased root growth to maximise exploration of the soil volume; and (3) better maintenance of plant cell structures to foster improved osmotic regulation. However, the extent to which white clover adaption may be extended remains an issue of further research. This review highlights an opportunity for further genetic improvement of white clover by focusing on improving the capacity to recover from periodic droughts through seedling regeneration. Further breeding efforts in white clover should examine the feasibility of selecting for hard seed characteristics more similar to the best-adapted subterranean clover (Trifolium subterraneum L.) cultivars across this region to promote ongoing seedling regeneration.
\end{abstract}

Additional keywords: fertiliser, hardseededness, nitrogen fixation, pasture persistence, soil pH, soil water.

Received 13 February 2019, accepted 6 June 2019, published online dd mmm yyyy

\section{Introduction}

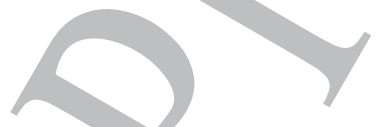

The permanent pasture region of south-eastern Australia broadly comprises $\sim 16$ million hectares of grazed pasture land on the eastern seaboard, spanning New South Wales (NSW), Victoria

5 and Tasmania. The landscape is typically undulating with soils that are commonly shallow, acidic and inherently low in fertility. Annual rainfall varies from $<500$ to $>1000 \mathrm{~mm}$, with seasonal distribution being more winter dominant in the Tasmanian environments to strongly summer dominant in northern 10 NSW. However, pasture growth rates are often constrained in winter due to low temperatures (Mills et al.2006) associated with high-latitude or high-altitude environments.

Legume production has long driven the productivity of grazing enterprises in these environments, fixing atmospheric nitrogen $(\mathrm{N})$ in the low fertility soils and providing high-quality protein forage for grazing livestock. The temperate annual legume subterranean clover (Trifolium subterraneum L.) has traditionally been the primary legume species used in southern areas of this region due to its high tolerance of grazing and acidic soils. However, subterranean clover is a self-regenerating 
winter-growing annual legume species that is poorly adapted to using favourable conditions for pasture growth during the summer months, limiting $\mathrm{N}$ inputs and constraining the productivity potential of the landscape. White clover

5 (Trifolium repens L.) is the most commonly used temperate perennial legume in this region, particularly in northern NSW (Pearson et al. 1997; Hill and Donald 1998). However, its persistence is unreliable due to its sensitivity to periodic moisture stress (Hill 1996). Future climate scenarios predict

10 highly variable seasonal conditions with a likely increase in the incidence of summer rainfall in this region (Cullen et al. 2012), increasing the urgency to find alternative legume options to the winter-growing annual species.

Soil properties are known to affect the apparent drought 15 severity experienced by plants. For example, aluminium toxicity associated with acidic soils is known to restrict root growth and reduce the volume of soil explored for moisture and nutrients. Soil inputs (fertiliser and ameliorants) to grazing systems that dominate much of this region have historically 20 been low and confined to, at best, annual applications of single superphosphate $(8.8 \%$ phosphorus $(\mathrm{P}), 11 \%$ sulfur $(\mathrm{S}))$ due to relatively poor returns from the grazing industries and a perception that top-dressing of lime is not economically feasible (Khairo et al. 2010). Molybdenum (Mo) was

25 traditionally applied routinely on many farms due to the known deficiency of this nutrient on acidic soils and its importance for $\mathrm{N}$ fixation in legumes (Anderson 1970), although recent farm surveys suggest that Mo application is low and irregular (Hackney et al. 2019). Application of other

30 nutrients, such as potassium $(\mathrm{K})$, is not as widely used in dryland grazing production systems, and soils in that region are increasingly becoming responsive to $\mathrm{K}$ fertiliser due to progressive depletion from product removal (Holland et al. 2018).

Seasonal rainfall is beyond the control of individual farmers, but is the key driver of pasture productivity and persistence underpinning the grazing industries. Improving pasture resilience to periodic drought and better using episodic rainfall is required for the grazing industries to adapt to a variable climate. It would seem that the legume component of the sward is the highest priority due to its relative vulnerability to moisture stress and the importance of biological $\mathrm{N}$ fixation to drive the productivity of the whole system. This review explores the proposition that increasing inputs to soil will improve the persistence and reliability of drought-sensitive perennial legume species in this region.

This review is set out in three parts. Part 1 , Perennial legumes, explores the available perennial legume options for the high-rainfall pasture zone, their physiology and past achievements in breeding for tolerance to moisture stress. Part 2, Soil constraints, describes the key soil factors that limit forage legumes with a particular emphasis on constraints that exacerbate moisture stress on plants. Part 3, Future opportunities, sets out some recommendations for future work. Throughout this review we refer to the 'target region' as being the potential zone of adaptation for white clover (Department of Health and Ageing 2004), which is generally confined to coastal and tableland environments of NSW and Victoria and the pastoral zones of Tasmania, although white clover could also be grown in small areas of other Australian states (Fig. 1).

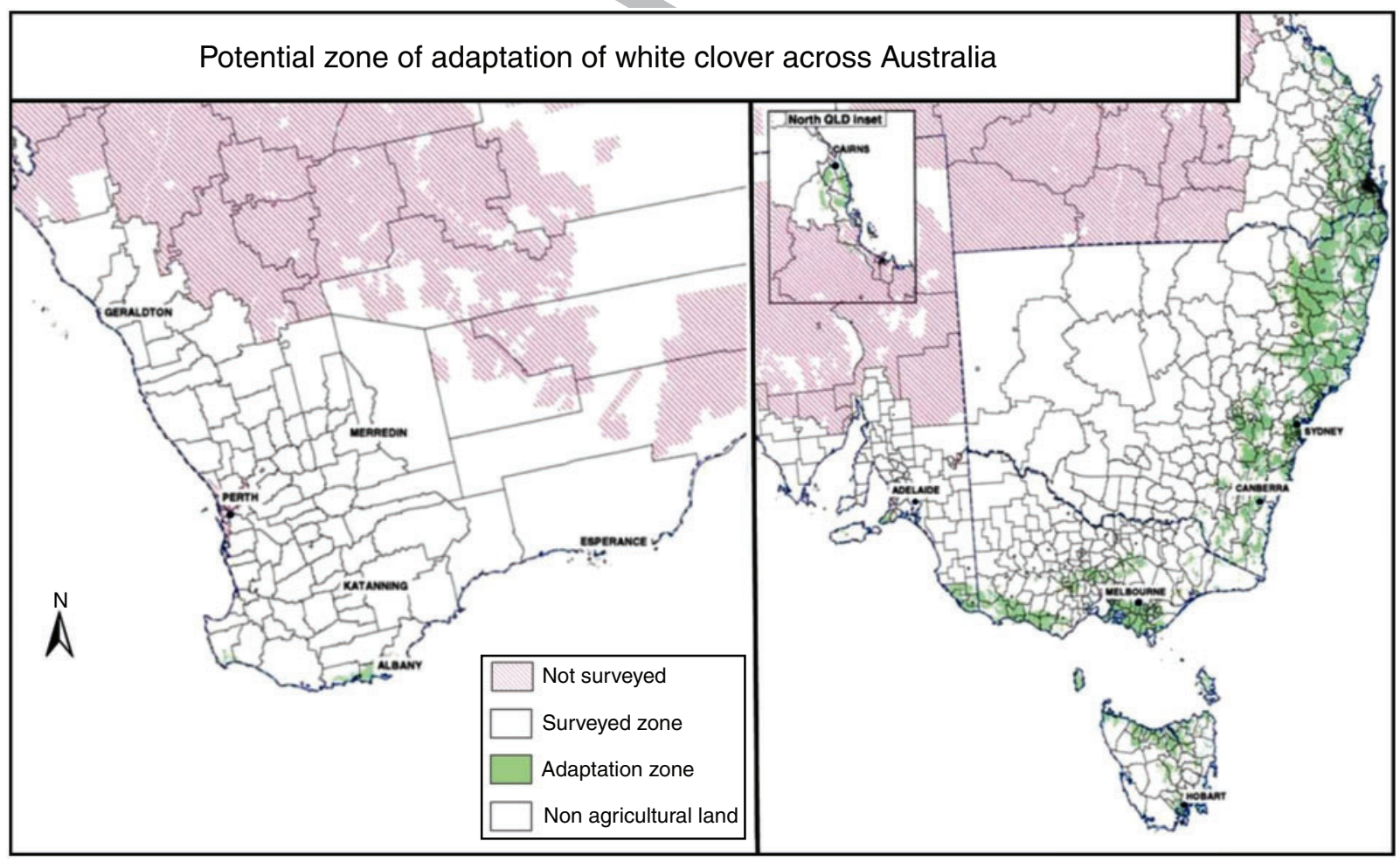

Fig. 1. Potential distribution of white clover (Trifolium repens L.) in non-irrigated Australian pastures (adapted from Department of Health and Ageing 2004). Qld, Queensland. 


\section{Perennial legumes}

Perennial legume options for the high-rainfall zone

Perennial legume options for permanent pastures in the mediumto high-rainfall region of south-eastern Australia are limited. The

5 four most widely used and available species are white clover, red clover (Trifolium pratense L.), strawberry clover (Trifolium fragiferum L.) and lucerne (Medicago sativa L.). White clover remains the most commonly used legume in the target region (Lane et al. 1997; Pearson et al. 1997; Hill and Donald 1998),

10 hence it is the focus of much of this review. The development of this species for the Australian market will be described in detail in a subsequent section. The use of tropical legume species across the target region is not widespread and thought to be highly restricted by low temperatures throughout the year. Therefore, this section focuses on temperate perennial legume species.

Recent advances in red clover cultivars have focused on grazing tolerance through exploiting stoloniferous growth habits and lower growing points (Smith and Bishop 1998) leading to better persistence. Nevertheless, its use in

20 permanent pastures has been limited by its sensitivity to moisture stress and relative sensitivity to aluminium toxicity in low pH soils (Dear et al. 2003). Strawberry clover warrants further investigation due to the large range in adaptation from waterlogged soils (Stevenson et al. 2017) to periods of moisture 25 deficit and high temperatures in drier environments ( $\mathrm{Li}$ et al. 2008). The cultivar Palestine, which was developed in the 1930s, remains the most widely used cultivar, perhaps owing to its broad adaptation, but also due to the relatively low demand in the Australian market. The large focus on lucerne in breeding 30 programs in Australia, particularly during the period 1977-2000 (Irwin et al. 2001), reflects the importance of this species in southern Australia. Lucerne breeding has been focused on persistence, winter activity, aphid and disease resistance and grazing tolerance. Acid soil tolerance remains an issue in lucerne and is the focus of some ongoing research (Hayes et al. 2011; Wigley et al. 2018). In New Zealand, the increased adoption of lucerne has been achieved through the development of management guidelines (by publicly funded research), supported by liveweight gain data and associated extension

40 activity (Monk et al. 2016). Nevertheless, lucerne adaptation in the high-rainfall permanent pasture environments of southeastern Australia would seem to be constrained by shallow and acidic soils.

Several alternative perennial legumes have been evaluated, developed and, in some cases, released commercially. Although many have shown they are well adapted to parts of the target region, other barriers constrain widespread adoption. Small market size (Bell et al. 2014), successful establishment and reliable seed supply at an acceptable cost are seen as major

50 barriers leading to low investment by the large seed companies (Monk et al. 2016) in an era when public investment in cultivar development has dwindled (Productivity Commission 2016).

Caucasian clover (Trifolium ambiguum M.Bieb.), for example, is slow to establish due to the high rate of partitioning of resources into the root (Genrich et al. 1998) and slow secondary shoot and leaf development (Black et al. 2006) leading to low competitiveness in mixed swards. Nevertheless, once established it can be a highly persistent species in the drier regions of the target environment (Dear and Zorin 1985; Virgona and Dear 1996). Similarly, the deep rooted Talish clover (Trifolium tumens Steven ex M.Bieb.) also has a high root: shoot ratio during establishment and slower rates of leaf appearance compared with other legumes (Murray 2012). Issues also remain with seed production and the availability of seed of both species to farmers (Bell et al. 2014).

Potential remains in the trefoil (Lotus) genus with birdsfoot trefoil (Lotus corniculatus L.), greater birdsfoot trefoil (Lotus pedunculatus Cav.) and, more recently, narrowleaf trefoil (Lotus tenuis Waldst. \& Kit. ex Willd) showing the most promise. Experimental varieties of $L$. corniculatus were developed for the high-rainfall temperate perennial pasture zone. These varieties expressed improved seed yield components and favourable agronomic performance at low latitudes in eastern Australia that would ensure sustained regeneration and population persistence under short daylength conditions (Ayres et al. 2008). A subsequent breeding initiative to develop L. corniculatus lines for more Mediterranean environments receiving $>600 \mathrm{~mm}$ annually was undertaken in Western Australia (Real et al. 2012) and although three cultivars have been registered for Plant Breeder's Rights in Australia, seed production issues and high seed costs limit uptake by farmers.

Sulla (Hedysarum coronarium L.), sainfoin (Onobrychis vicifolia Scop.) and alsike clover (Trifolium hybridum L.) all have potential in specific conditions (Li et al. 2008), and although Trifolium uniflorum $\mathrm{L}$. has been used for hybridisation with white clover to enhance persistence traits (Williams 2014), this novel material is yet to make its way to the Australian seed market. Sulfur clover (Trifolium ochroleucum Huds.) and zig-zag clover (Trifolium medium L.) also offer some potential, but have received little attention from Australian researchers to date.

\section{Perennial legume physiology}

The perennial species of the Trifolium genus are generally stoloniferous or rhizomatous in habit, with root depth varying according to species. Within the Trifolium spp. some intraspecific variation for rooting depth reportedly exists, such that purportedly a deep rooting cultivar of white clover, namely cv. Dusi, has been bred (Norton and FitzGerald 1993). During its juvenile stage, white clover is primarily dependent upon a taproot, but once mature the primary vegetative structure is a stolon with roots arising from the stoloniferous nodes (Caradus 1990). In this context, it is of note that in response to soil moisture deficit white clover does not allow the water potential of its stolons to decline as readily or as far as occurs in its leaves and petioles (Turner 1990).

White clover tends to act either as a perennial in temperate, moist climates, where it is primarily dependent on its stolons for survival (Archer and Robinson 1989), or as an annual in seasonally moist, subtropical, coastal regions, where its short season of growth, typically in spring, is dependent upon prolific seed production (Archer and Rochester 1982), a high proportion of which is hard. There is an inverse relationship between stolon branching and flowering vigour. Therefore, profusely flowering white clover populations have the potential to produce a large number of seeds but tend to have fewer stolons (Thomas 1987; Department of Health and Ageing 2004). The presence of 
effective pollination is essential for maximising seed yield in white clover, with honey bees (Apis mellifera) increasing commercial seed yields 10-fold in Australia (Lane et al. 2000). Long-term water stress promotes the production of 5 white clover inflorescences, but increases floret abortion and the premature death of whole flower heads, as well as reducing the number of ovules per floret (Turner 1993). Nevertheless, white clover seed size is very small at $\sim 6 \times 10^{-3} \mathrm{~g}$, and smallseeded Trifolium species have previously been demonstrated to

10 be at a relative advantage in proliferating seed during dry spring conditions relative to larger-seeded species (Hayes et al. 2008). L. corniculatus is another perennial forage legume that relies on significant regeneration from seed for persistence (Ayres et al. 2007b).

15 Species within the Trifolium genus that are considered of superior persistence are often of rhizomatous habit (e.g. Caucasian clover) with the primary vegetative structures, rhizomes, existing underground. Alternatively, they may be of stoloniferous or taprooted habit, but are reported also to have

20 their primary growing points underground (e.g. Talish clover). Presumably the protection of the plant's growing points from grazing, that being underground confers, improves the persistence of these species. It is of note that in Australia both Caucasian and Talish clovers have been 25 developed more for the low-input, cool and drier temperate environments such as the Monaro Plateau of NSW (Virgona and Dear 1996) and the Tasmanian Midlands (Hall et al. 2013) where grazing management is often minimal and white clover persists poorly.

30 In contrast, the persistence of lucerne, particularly in dry climates, is facilitated by its deep taproot, which is able to access water to considerable depth. Maximum rooting depth is influenced by soil type and stand age, but lucerne has been reported to be able to extend roots as deep as $6 \mathrm{~m}$ below the soil

35 surface (Black et al. 1981), substantially deeper than the $\sim 0.6 \mathrm{~m}$ rooting depth of white clover (Archer and Robinson 1989). Conversely, the two trefoils, although also taprooted, do not have the same reputation for drought hardiness as lucerne. Part of the reason for this may be because their taproot is not as extensive

40 as that of lucerne, as water scavenging selection pressures never acted on these species because they evolved in much less arid climates (Britain, Ireland, Western Europe).

White clover expresses limited water conservation traits, which is further constrained by its shallow roots that limit 45 exploration of soil water. Johns (1978) compared it to perennial ryegrass (Lolium perenne L.), phalaris (Phalaris aquatica L.) and tall fescue (Festuca arundinacea Schreb.), whereas Aparicio-Tejo et al. (1980) included two lucerne cultivars and subterranean clover. In both studies it was the

50 most profligate user of water that demonstrated the least ability of any of the species to restrict water loss by reducing stomatal conductance. Indeed, water use of the white clover swards was mainly reduced through leaf senescence of the sward, which clearly indicates that white clover is not well adapted as a forage

55 where soil moisture deficit is common. For satisfactory growth, white clover requires ready access to water. It has a superior ability to store carbohydrates and recover following a short drought compared with perennial ryegrass (Karsten and MacAdam 2001), but it has reduced access to soil water due to a shallower rooting system (Liu and Kemp 1992; Karsten and MacAdam 2001).

Lucerne has a reputation as a drought-resistant species and is used in mixed farming environments with annual rainfall as low as $350 \mathrm{~mm}$ (Latta et al.2001). Its deep root system is crucial to its survival in such environments (Brown et al. 2005) because this allows the maintenance of the minimum water status necessary for survival, the internal water content beyond which a plant will not recover following rehydration. When challenged by severe soil moisture deficit, lucerne will shed its leaves because this reduces transpiration, thus facilitating the maintenance of its threshold minimum water status. When subjected to an environment where the plant was unable to draw on 'deep water' and having shed all of its leaf, lucerne reached its lethal minimum water status quicker than a range of other pasture species (no other legumes were included in the study), including cocksfoot (Dactylis glomerata L.) and tall fescue, and so suffered greater mortality than these other species (Volaire 2008). Thus, according to the plant drought response strategy terminology (Turner 1986; Ludlow 1989), lucerne would be characterised as a dehydration avoider rather than a dehydration tolerator.

Success in breeding for drought-tolerant white clover in Australia

Selecting for improved tolerance to moisture stress is a primary breeding objective for dryland environments not only in Australia, but also in Japan, New Zealand, South Africa and the US (Smith and Morrison 1983; Caradus 1991; Ayres et al. 1996). For Australian dryland pastures, improving stolon survival during periodic moisture stress in summer-autumn has been the primary breeding objective for new white clover cultivars (Ayres et al. 1996). Little emphasis has been placed on the development of traits for seedling regeneration, presumably due to the perception that white clover is slow to recover to full production following seedling recruitment (Archer and Robinson 1989).

White clover breeding in Australia and New Zealand commenced in the late 1920s looking for improved agronomic performance from local ecotypes (Caradus et al. 1995). Prior to the registration of Haifa in 1971, cultivars commonly used in Australia (Peterson 1987) were New Zealand varieties, such as Huia (Archer and Gressor 1979). Haifa, developed from germplasm from Israel, had higher heat tolerance, winter activity and seedling regeneration than the New Zealand cultivars. However, persistence was poor, which was attributed to poor stolon growth and low tolerance to close grazing (Lane et al. 2000). Haifa remains one of the most widely used cultivars in Australia, believed to comprise approximately $65 \%$ of the domestic seed market (Nichols et al. 2012). Despite the success of Haifa, there was a recognised lack of locally adapted white clover cultivars for Australia, particularly for dryland environments, resulting in the formation of a national white clover program at Glen Innes in the Northern Tablelands of NSW (Curll 1987). This national program later evolved into two breeding programs, both with strong industry and commercial support. One breeding program was conducted by Victorian Department of Primary Industries
10 
and focused on white clover for high-rainfall and irrigated dairy pastures (Jahufer et al. 2012). The other breeding program, conducted by NSW Department of Primary Industries based at Glen Innes, focused on white clover for beef and sheep dryland 5 pastures with an emphasis on improved persistence under conditions of summer moisture stress, heat stress and close grazing (Ayres et al. 1996). From 1994 this program became an Australasian program in collaboration with AgResearch (New Zealand) and industry support. The following case studies 10 outline two examples of successful white clover cultivar development for south-eastern Australia.

\section{Grasslands Trophy}

Grasslands Trophy, a medium- to large-leafed white clover, released from the Australasian programme was developed from an in situ breeding program that: (1) identified and selected superior genotypes; (2) crossed elite germplasm; and (3) tested progeny derived from breeding lines for the expression of key agronomic and grazing value traits (Ayres et al. 2007a). The selection criteria were early vigour, herbage yield, persistence and seed yield potential. Grasslands Trophy was developed as a polycross of four family populations that originated from southern France, Portugal, the US and the Mediterranean basin. Parental selection was also applied for seed yield, uniformity of leaf size, uniform flowering pattern and freedom from disease and virus symptoms (Ayres et al. 2007a). Grasslands Trophy combines intermediate stolon density with intermediate stolon thickness, and expresses high stolon survival and strong autumn regrowth following summer moisture stress. Grasslands Trophy has midseason flowering maturity, intensive flowering prolificacy and high seed yield capability.

Agronomic results from two experiments in the Northern Tablelands of NSW indicated that Grasslands Trophy exhibited broad adaptation, expressed high summer and winter growth activity and was persistent at these sites for at least 4 years despite fluctuations in monthly rainfall and severe periodic moisture stress. Grasslands Trophy expressed early vigour comparable with Haifa and significantly better summer growth than check cultivars including Haifa. Winter and spring growth was comparable to the highly winter-active

40 cultivar Haifa. At the Armidale site, Grasslands Trophy exhibited a high level of stolon survival (78.6\%) following severe summer moisture stress compared with the check cultivars, which, on average, retained approximately $50 \%$ of stolons over the same period (Ayres et al. 2007a).

The relative performance of Grasslands Trophy was further evaluated under cattle grazing at Glenormiston, south-west Victoria, Australia (Jahufer et al. 2009). Grasslands Trophy exhibited high persistence with an average clover content within seasons and across seasons and years higher than the 50 control cultivars. Despite its favourable performance, Grasslands Trophy is no longer commercially available in Australia.

\section{Grasslands Tribute}

Grasslands Tribute was released in 2003 from a collaborative 55 program started in 1991 to select white clover with tolerance to drought stress (Woodfield et al. 2003). The cultivar was originally developed from a collection of 20 white clover lines that included several Australian ecotypes, a range of New Zealand cultivars and breeding lines, and three ecotypes collected from southern Europe and Syria. The selected lines exhibited drought tolerance, rust resistance and high dry matter (DM) yield (Caradus et al. 1991; Barker et al. 1993; Woodfield et al. 2003). From this material, 45 genotypes that exhibited high persistence and herbage yield were selected from four lines: Sustain, Crau, Southern Europe II and Syrian. After polycrossing, 45 half-sib families were screened in Victoria with four control cultivars. After 2 years, 25 half-sib families were selected for improved autumn-winter growth and drought tolerance. These half-sib families were further screened and elite plants from 11 half-sib families originating from Sustain, Crau, Southern Europe II and Syrian were recombined to produce Grasslands Tribute, a medium- to large-leafed white clover. Grasslands Tribute exhibited consistent performance and persistence under dryland grazing in a series of seven New Zealand experiments (Woodfield et al. 2003). It was the best medium- to large-leafed cultivar under both sheep and dairy grazing, with only the large-leafed cultivar Kopu II performing better under dairying. Grasslands Tribute showed strong growth in all seasons, but had very good cool season growth and good drought tolerance (Woodfield et al. 2003). Grasslands Tribute is still available commercially in Australia.

The breeding programs outlined above focused on selecting for improved tolerance to moisture stress and agronomic performance, and the cultivar descriptions provide little information on the soil fertility status and nutrient applications to the field screening and evaluation experiments. It is therefore uncertain whether these elite cultivars would be expected to confer even greater advantage under drought with increased soil fertility levels.

\section{Impact of grazing on perennial legume drought survival}

When assessing the impact of grazing on the persistence of perennial legumes there are several factors that should be considered: (1) how the intensity and timing of defoliation directly affects stolon or tiller survival and production; (2) how selective grazing affects grass-legume competition (Leigh and Holgate 1978); and (3) the impacts on flowering and seed production (Archer and Robinson 1989; Hutchinson et al. 1995; Lane et al.2000). The role of trampling and excreta on legume persistence is likely to be minimal, although the excreta can be important for seed dispersal in some species (Curll and Jones 1989).

Maximum growth rate of white clover occurs at $24^{\circ} \mathrm{C}$ but is very similar in the range $18-30^{\circ} \mathrm{C}$ (Harris 1987). On the Northern Tablelands of NSW, the chance of mortality increases when mean maximum temperature exceeds $20^{\circ} \mathrm{C}$ and monthly rainfall drops below 35 mm (Archer and Robinson 1989). Recovery of plants occurs due to regrowth of surviving stolons during the cooler months when soil moisture increases. However, once mature plants are lost, then recruitment from seed is required to maintain populations. In a 30-year study in northern NSW (1964-93), heavy grazing pressure resulted in poor white clover recovery following an early drought, whereas at light and moderate stocking rates white clover persisted until a severe 
drought during 1980-82 (Hutchinson et al. 1995). The decreasing recovery due to drought was thought to be a failure of seed-based regeneration. By 1981, seed reserves were threefold lower in the high-stocking rate treatment 5 compared with the light- and moderate-grazing treatments. With high grazing pressure there was also a greater invasion of annual species, which provided additional competition with the establishing white clover seedlings. Plants weakened by defoliation may also be more prone to insects and pathogens

10 (Curll and Jones 1989).

The prostrate growth of white clover ensures that many growing points are below grazing height and most stolons survive defoliation (Curll and Jones 1989), allowing plants to spread into gaps (Lane et al. 2000). Increasing grazing pressure

15 can reduce stolen length per unit area and the proportion of clover (i.e. $25.4 \mathrm{~m} \mathrm{~m}^{-2}$ and $18 \%$ clover vs $94.8 \mathrm{~m} \mathrm{~m}^{-2}$ and $45 \%$ clover for stocking rates of 50 and 25 sheep ha ${ }^{-1}$ respectively; Curll and Wilkins 1981; Curll and Jones 1989). In one study, the increased stocking density caused an $80 \%$ higher defoliation frequency of 20 clover plants, reducing leaves by $63 \%$ and stolons by $79 \%$ (Curll and Wilkins 1982). Under high grazing pressure many cultivars of white clover can develop a prostate growth habit with short petioles, high leaf and root node densities (per unit stolon) and many small leaves able to avoid defoliation. However, under 25 light grazing the plant grows larger leaves, longer petioles and has a lower leaf node density to help reduce shading from companion grasses (Curll and Wilkins 1985; Curll and Jones 1989). Archer and Robinson (1989) showed that white clover persisted better under a regime of regular grazing every 4 weeks

30 compared with a more 'lenient' regime where pastures were able to recover for 8-24 weeks before being cut to a low height. The more frequent grazing presumably helps maintain the prostrate growth habit and protects growing points.

In glasshouse studies that compared the effects of high and

35 low soil P fertility, as well as defoliation frequency of white clover response to drought stress, high soil P status significantly alleviated the effect of drought under high and low defoliation frequencies despite plants in the high-P treatment drying the soil more (Singh et al. 1997; Singh and Sale 2000). High P-fertility

40 and infrequently-defoliated plants had the highest evapotranspiration rate and driest soil (Singh et al. 1997) with the highest shoot mass (Singh and Sale 1997). However, they maintained higher leaf water potential, exhibited fewer water stress symptoms and recovered faster than low P-fertility plants.

45 High P-fertility and frequently-defoliated plants were most resistant to the effects of drought, indicating a role for grazing management on white clover drought stress, well recognised in New Zealand in the context of stolon surviyal (Brock and Kim 1994).

\section{Soil constraints}

Prioritising the particular soil constraints to be addressed to improve the drought survival of legumes will be determined by the extent and magnitude of the constraint across the target region and the role of the particular constraint in exacerbating the

55 frequency, duration or severity of drought. A framework for prioritising the relative importance of particular soil constraints in this region is set out in Table 1, based primarily on their

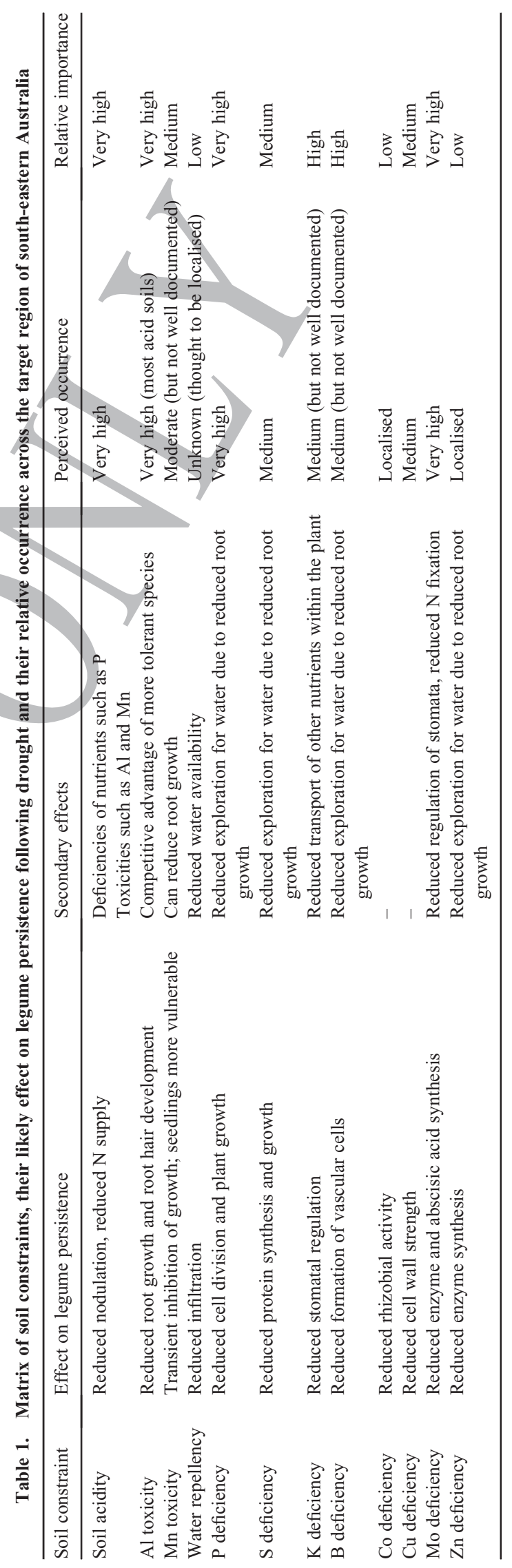


distribution. However, some soil constraints have a direct effect on a plant's ability to deal with drought through impeded root growth or reduced internal osmotic regulation at the cell level, and so addressing these impediments would likely have a direct 5 effect on the response of drought-sensitive legume species.

\section{Effects of soil acidity on root growth of pasture legumes}

It is well documented that soil acidity has significant negative effects on plant growth in legume-based pastures, hence reducing $\mathrm{N}$ inputs of legumes (Unkovich et al. 1996). The soluble toxic Al

10 ion complex associated with low soil $\mathrm{pH}$ not only reduces root growth, but also supresses the proliferation of rhizobium (Evans et al. 1988) and reduces the efficiency of nodulation (Richardson et al. 1989) and N fixation in legume species (Peoples et al. 2012).

Soil acidity could represent the most widespread threat to the

15 symbiotic performance of legumes in pastures of south-eastern Australia. The introduction and use of acid-tolerant host germplasm and rhizobial strains may provide a potential solution to poor symbiotic performance in acid soils (Howieson and Ewing 1986; Howieson et al. 1988; Wigley

20 et al. 2018). In conjunction, lime application to ameliorate soil acidity may increase soil populations of rhizobia and enhance root nodulation (Evans et al. 1988; Richardson et al. 1989), stimulate nodule nitrogenase activity (Coventry et al. 1985) and manage reacidification of soil in a long-term pasture (Li et al. 2019).

A common visual symptom of acidic soil stress is short and stubby roots caused by Al toxicity (Hayes et al. 2011). Aluminium is commonly present in soils as insoluble aluminosilicate minerals and oxides associated with kaolin 0 and other clay minerals. As the soil $\mathrm{pH}_{\mathrm{Ca}}$ drops below 5, Al is solubilised into the soil solution, with $\mathrm{Al}^{3+}$ the most important rhizotoxic Al species (Kochian et al. 2005).

Root growth depends on continued cell division and cell elongation, and these important processes occur at the root 5 apices. Root apices are the primary site for Al toxicity (Ryan et al. 1993). Aluminium does not have to enter the root cells to cause stress. Interactions in the apoplast can cause damage (Horst et al. 2010) and root growth inhibition upon exposure to $\mathrm{Al}$ happens rapidly. Prolonged exposures lead to Al interactions

40 with the root cell nuclei, resulting in disruption of cell division and the cytoskeleton (Kochian et al. 2005). Aluminium toxicity results in inhibited root elongation, which yields swollen root apices and poor or no root hair development. This extensive root damage results in a reduced and damaged root system and limited 5 water and nutrient uptake. The degree of toxicity varies widely depending on the plant species, growth conditions, $\mathrm{Al}$ concentrations and duration of exposure (Kochian et al. 2005).

Many plant species developed Al-resistance mechanisms during their evolution and significant variation in resistance 50 occurs in most important crop and pasture species (Ryan 2018). Aluminium resistance can be achieved by mechanisms that facilitate $\mathrm{Al}$ exclusion from the root apex and/or by mechanisms that confer the ability of plants to tolerate $\mathrm{Al}$ in the plant symplasm (Kochian et al. 2005). For Al-exclusion mechanisms, the plant root exudes organic compounds (such as organic acids or phenolics) into the rhizosphere and prevents toxic $\mathrm{Al}$ species, such as $\mathrm{Al}^{3+}$, from interacting with the apoplast.
For Al-tolerance mechanisms, the plant root allows the toxic Al species to enter the plant, and then sequesters and detoxifies them in subcellular compartments and/or translocates them away from the root tip.

Manganese $(\mathrm{Mn})$ toxicity can also be a factor inhibiting plant growth on some acidic soils (Schlichting and Sparrow 1988) and has been reported as an important factor limiting the utilisation of sensitive perennial legumes, such as lucerne, in the target region of south-eastern Australia (Siman and Flemons 1970). Toxicity attributable to Mn is governed by: (1) the concentrations of easily reducible $\mathrm{Mn}$ in the soil; and (2) biological processes that lead to Mn being available in the reduced form $\left(\mathrm{Mn}^{2+}\right)$, such as high soil temperatures or waterlogged soil conditions. As such, Mn toxicity is often transient in nature and likely to affect legume performance most at the seedling stage (Hayes et al. 2012).

Adaptation to acidic soils of perennial forage legumes varies between species. Lucerne is highly sensitive to both $\mathrm{Al}$ and $\mathrm{Mn}$ toxicities (Bouton 1996; Hayes et al. 2012). In a solution screening experiment comparing perennial legume tolerance to both toxicities, McVittie et al. (2012) ranked the species in decreasing order of tolerance to $\mathrm{Al}$, based on reduction of root length relative to the untreated control as follows: L. pedunculatus, white clover, Talish clover, birdsfoot trefoil, Bituminaria bituminosa L., Caucasian clover, red clover, lucerne, strawberry clover, Cullen australasicum. The decreasing order of tolerance of $\mathrm{Mn}$, based on the reduction of shoot weight, relative to the untreated control, was birdsfoot trefoil, Caucasian clover, C. australasicum, red clover, Talish clover, strawberry clover, L. pedunculatus, white clover and lucerne. These results are in broad agreement with previous hydroponic experiments, although substantial differences between cultivars in species such as white clover have been noted (Wheeler and Dodd 1995). If these responses are validated under field conditions, there is potential that white clover roots would be less affected by Al toxicity than other species, and that Talish clover, Caucasian and birdsfoot trefoil would also be relatively well adapted to acidic soil, should they become more readily available to farmers.

\section{Effects of soil acidity on nodulation of pasture legumes}

The capacity of legumes to fix $\mathrm{N}$ depends on the formation of nodules by root nodule bacteria (rhizobia) and the effectiveness of the occupant rhizobium to fix N. Rhizobial inoculants are selected to be effective at fixing $\mathrm{N}$ with the target host legumes and able to persist in soil. However, soil factors (e.g. acidity and associated $\mathrm{Al}$ and $\mathrm{Mn}$ toxicities; high plant-available $\mathrm{N}$ or inadequate available $\mathrm{P}, \mathrm{S}, \mathrm{Mo}$ ) and background populations of less-effective rhizobia may mean that legumes do not always form effective root nodules, thereby compromising $\mathrm{N}$ fixation (Table 2; Slattery and Pearce 2002; McInnes et al. 2004; McInnes and Haq 2007).

Giller (2001) suggested that the potential $\mathrm{N}$ fixation rate should be more than $1 \mathrm{~kg} \mathrm{~N}^{-1}$ day $^{-1}$ during the growing season for all legumes. However, the actual $\mathrm{N}$ fixation rate is much less, with great variation for pasture species in the temperate region. Peoples et al. (2012) showed that the $\mathrm{N}$ fixed in shoots was in the range $2-284 \mathrm{~kg} \mathrm{~N} \mathrm{ha}^{-1}$ (mean $83 \mathrm{~kg}$ $\mathrm{N} \mathrm{ha}^{-1}$ ) per year for lucerne, $7-236 \mathrm{~kg} \mathrm{~N} \mathrm{ha}^{-1}$ (mean $42 \mathrm{~kg} \mathrm{Nha}^{-1}$ ) 
Table 2. Pasture and soil attributes that may affect perennial legume persistence and $\mathbf{N}$ fixation in south-eastern Australia (adapted from (Abbott and Murphy 2007)

SOC, soil organic carbon

\begin{tabular}{lll}
\hline Factor $\quad$ Legume host & Rhizobial strain persistence and root-nodulation
\end{tabular}

\section{Pasture}

Legume

Non-legumes

(i.e. grasses) establishment and inoculation

\section{Acidity}

Soil

Major plant nutrients $(\mathrm{N}, \mathrm{P}, \mathrm{K}$ and $\mathrm{S}$ )

SOC

Soil temperature

Soil moisture content and waterholding capacity
High N-fixation can shift pasture composition to more $\mathrm{N}$-responsive species (e.g. annual grasses)

Legume persistence is jeopardised by competition and shading (Dear et al. 1998)

Common decline in legume content of pastures over time due to competition, management, and season Increased prevalence of background ecotypes that may be less productive
Increased population and persistence with legume host (Chatel and Parker 1973; Bottomley 1992; Thies et al. 1995)

Host may favour nodule occupancy by selected strains (Bottomley 1992)

Some legumes host effective strains from mixed populations (Yates et al. 2005)

Generally increased population in rhizosphere relative to soil, but not more than legume host plants (Parker et al. 1977; Lowendorf 1980)

May decrease population due to some root exudates and microbial products (Lowendorf 1980; Slattery et al. 2001)

Increased nodulation where non-legumes reduce soil $\mathrm{N}$ pool (Brockwell et al. 1995)

Root nodulation with rhizobial strain applied as a seed inoculant more likely at time of sowing, and may decrease with time due to edaphic factors and background rhizobial strains (Slattery and Pearce 2002)

More diverse population of rhizobia likely with time since pasture establishment (McInnes et al. 2004)

Some legumes form root nodules with a variety of strains, thus have a range of $\mathrm{N}$-fixation effectiveness with time since inoculation (McInnes et al. 2004).

Some strains are sensitive to soil acidity due effects on nutrient availability, such as reduced available $\mathrm{P}$ and $\mathrm{Ca}$ and increased Al (Evans et al. 1988; Bottomley 1992) and Mn (Lowendorf 1980) development of some sensitive legumes (Unkovich et al. 1996; Dilworth et al. 2000)

Soil acidity reduces the availability of some essential plant nutrients (e.g. $\mathrm{P}$ and $\mathrm{Ca}$ ) and increases the availability of other toxic elements (e.g. Al and Mn; Bouton 1996; Hayes et al. 2012)

Increased $\mathrm{NO}_{3}{ }^{-}$leaching under pasture swards dominated by legumes is associated with soil acidification

Perennial legumes vary in their nutrient foraging potential nutrients (e.g. P; Kidd et al. 2016; Yang et al. 2017)

Pasture legume biomass and $\mathrm{N}$ fixation under $\mathrm{P}, \mathrm{K}$ and $\mathrm{S}$ deficit is similar, suggesting relatively equal importance (Divito and Sadras 2014)

Little evidence linking the long-term persistence of perennial legumes to soil fertility (Singh et al. 2000)

SOC is positively correlated with improved soil physical condition and hydraulic properties (Haynes and Naidu 1998), including increased plant-available water (Hayes et al. 2017), but recent evidence questions the extent to which this occurs (Minasny and MeBratney 2018)

$\mathrm{Mn}^{2+}$ toxicity accentuated at high soil temperatures (Hayes et al. 2012)

White clover growth rates are typically optimal at soil temperature $18-30^{\circ} \mathrm{C}$ (Harris 1987)

Some deep-rooted perennial legumes (e.g. lucerne) are capable of accessing moisture deeper in the soil profile than annual legumes (Sandral et al. 2006), whereas others (e.g. white clover) have the majority of roots restricted to the surface soil

Liming has been shown to increase access to soil moisture (Hayes et al. 2016)
Liming soil can increase population size and persistence for acid-sensitive

rhizobia (Lowendorf 1980; Evans et al. 1988; Brockwell et al. 1995; Unkovich et al. 1996)

Limited nodulation where root growth and root hair development are retarded (Richardson et al. 1989; Bottomley 1992; Slattery et al. 2001)

Nodules formed in acidic soils typically contain more acid-tolerant strains (Bottomley 1992; Slattery et al. 2001)

Soil with high $\mathrm{N}$ can support large populations of rhizobia, but strain

persistence may be compromised where legume root nodulation is limited (Bottomley 1992; Brockwell et al. 1995)

Generally, population size and persistence are positively correlated with available P (Brockwell et al. 1995; Lindström et al. 2010) and in some cases K (Parker et al. 1977; Divito and Sadras 2014)

Available $\mathrm{P}, \mathrm{S}, \mathrm{Mo}$, B positively affect nodulation, occupancy and $\mathrm{N}$ fixation (Brockwell et al. 1995; McInnes et al. 2004; Yates et al. 2005; Divito and Sadras 2014)

Nodulation and nodule function are more sensitive than biomass production to deficiency of P, K and S (Divito and Sadras 2014)

Persistence and nodulation positively correlated with clay content and organic carbon concentration due to protection from predators (Barnet 1991), desiccation and temperature (Bottomley 1992) and water- and nutrientholding capacity (Divito and Sadras 2014)

Survival varies between strains (Chatel and Parker 1973); typically decreased persistence and population size with increased soil temperature (Parker et al. 1977; Barnet 1991; Bottomley 1992)

Temperature (extreme high and low) affects nodule occupancy (Bottomley 1992) and reduces nodule initiation and formation (McInnes and Haq 2007)

Decreased persistence, population size and competitiveness with low soil moisture (Lowendorf 1980; Barnet 1991; Bottomley 1992) and potentially waterlogged conditions (Parker et al. 1977), but not always (Lowendorf 1980; Brockwell et al. 1995)

Low soil moisture may reduce nodulation (Bottomley 1992; Brockwell et al. 1995) 
for white clover, 5-174 $\mathrm{kg} \mathrm{N} \mathrm{ha}^{-1}$ (mean $65 \mathrm{~kg} \mathrm{~N} \mathrm{ha}^{-1}$ ) for subterranean clover and 2-167 $\mathrm{kg} \mathrm{N} \mathrm{ha}^{-1}$ (mean $56 \mathrm{~kg} \mathrm{~N} \mathrm{ha}^{-1}$ ) for annual medics. Differences in $\mathrm{N}$ fixation result from variations in the proportion of the legume- $\mathrm{N}$ derived from atmospheric $\mathrm{N}$ and/

5 or the amount of legume-N accumulated during growth (Peoples et al.2012). The former is determined by survival and persistence of rhizobia and efficiency of nodulation (Graham and Vance 2003), as well as the mineral $\mathrm{N}$ content of the soil, whereas the latter is affected by various constraints, including adverse soil 10 conditions, such as soil acidity, moisture stress and inadequate soil nutrition (such as low $\mathrm{P}$ or Mo).

The adequacy of the population of effective rhizobia in the soil is one of the most critical factors that determine a legume's ability to nodulate and fix atmospheric $\mathrm{N}_{2}$ (Thies et al. 1991).

15 Growth of rhizobia within the root rhizosphere and colonisation of the root surface before infection is the first requirement for successful nodulation. Growth of bacteria at the root surface is facilitated by the presence of plant-released organic exudates (Richardson et al. 1989). In general, a high rate of nodulation 20 occurs together with high numbers and faster initial rate of growth of rhizobia. In acidic soils, despite a large population of rhizobia in the rhizosphere, nodulation may be limited by poor rhizobial growth (Ballard et al. 2003) and poor root infection (Richardson et al. 1989). Richardson et al. (1989) identified three 25 important factors that adversely affect the inducibility of nodulation gene expression in Rhizobium leguminosarum bv. trifolii in acidic environments: (1) the inability of the bacteria to initiate rapid growth at low $\mathrm{pH}$ and in the presence of $\mathrm{Al}$; (2) lower nodulation (nod) gene-inducing activity of clover seedling

30 exudates at low $\mathrm{pH}$; and (3) acid and Al sensitivity of the inducibility of nod gene expression in the presence of flavone inducer.

In solution culture, increasing $\mathrm{Al}$ concentrations reduce rhizobial proliferation and nodulation (Evans et al. 1988).

35 Evans et al. (1990) reported that although a decline in nodule number is frequently associated with an increase in average nodule weight, which may compensate the ability of $\mathrm{N}$ fixation, loss of more than $50 \%$ of potential nodule formation resulted in a substantial $(>10 \%)$ reduction in the potential yield of

40 DM. Liming acid soil increased establishment of Rhizobium trifolii and the rate of root nodulation (Evans et al. 1988). Bestpractice legume seed inoculation and liming the soil before sowing could help the infection and root nodule formation in the establishment year in acid soils. However, in 45 subsequent years the commercially available rhizobial strain (i.e. RRI128; Sinorhizobium (Ensifer) meliloti) used for lucerne may be challenged to persist, colonise and renodulate lucerne plants (Ballard et al. 2003). In sensitive species such as lucerne, rhizobial strains selected specifically for enhanced 50 performance under acidic conditions, such as strain SRDI736, may be required to help ensure effective nodulation and persistence (Wigley et al. 2018).

\section{Enhancing pasture access to moisture in acid soils}

Application of lime to alleviate Al toxicity has the potential to

increase access to soil moisture by the root systems of sensitive pasture species. Lime application can also affect the growth and survival of pasture species due to the higher availability of various nutrients, enhancement of $\mathrm{N}$ fixation by legumes and modification of soil physical properties (Wheeler and O'Connor 1988).

Lime application was largely ineffective in increasing soil water use by an annual grass-clover pasture in south-east Australia, but increased that of a deeper-rooted, perennial grass-based pasture (White et al. 2000) despite increasing the productivity of both pasture types (Li et al. 2006). Hayes et al. (2016) found that lime application increased the soil water deficit by up to $27 \mathrm{~mm}$ from less acidic subsoil well below the limed layer by phalaris, a species with moderate sensitivity to acid soils, and the more acid soil-sensitive lucerne, but not by more acid soil-tolerant species such as chicory (Cichorium intybus L.), tall fescue or cocksfoot. Growth was increased by lime application but only the persistence of lucerne was significantly increased. Further work was indicated to determine whether increased use of deep soil water by phalaris and lucerne with lime was due to alleviation of acid soil factors such as Al toxicity or to increased demand for water associated with higher herbage growth.

Unlike phalaris and lucerne, white clover has a shallow root system with typically at least $80 \%$ of roots found in the surface 20 $\mathrm{cm}$ of soil (Caradus 1990; Annicchiarico and Piano 2004). This may limit the extent to which lime application to acid soils can markedly increase access by white clover to soil moisture. Lime responses by white clover have been observed on acid soils containing Al at potentially toxic levels in Australian (Helyar and Anderson 1970; Hayes et al. 2012) and New Zealand (Edmeades et al. 1983) soils. Shannon et al. (1984) found that a sample of nine New Zealand pastures were most responsive to lime in the summer-autumn period but did not determine the cause for this seasonal pattern. Similar results were obtained for a ryegrass-white clover pasture on an acid krasnozem soil in north-west Tasmania (Rowe and Johnson 1988).

Hayes et al. (2012) observed a large response to lime by Haifa white clover up to 26 months after sowing on a highly acidic soil in southern NSW. Because lime reduced Al to negligible levels in the $0-50 \mathrm{~mm}$ layer, it was argued that this may have been due to increased root growth and exploration in the $0-50 \mathrm{~mm}$ and possibly deeper layers. As noted above, other factors may also have contributed. On a deeper soil in the same area, Hayes et al. (2010) observed a higher soil water content in the $0-30 \mathrm{~cm}$ layer for up to 10 months after lime application, despite $30 \%$ higher pasture growth, and postulated that lime may have increased infiltration rates by reducing water repellency (hydrophobicity) of the surface soil. Therefore, an additional benefit of lime related to higher soil moisture content was suggested.

Water repellency is widely observed on sandy soils in regions with Mediterranean climates in southern Australia (Roper et al. 2015). The extent to which it affects soils in the target region of south-eastern Australia is unknown, but this zone can also experience long dry periods at any time of the year, so water repellency could arise in some situations, as suggested by Hayes et al. (2010), particularly if the soil has a coarse surface texture. A range of physical and chemical interventions is available to ameliorate water repellency (Roper et al. 2015). In the context of acid soils, Roper (2005) showed that lime application markedly reduced water repellency both in the laboratory and in the field. Rapid responses were likely associated with physical soil properties and more gradual changes to biological activity 
associated with increased activity of wax-degrading bacteria. Roper (2005) also showed that reductions in water repellency from lime applications of 10 or $15 \mathrm{t} \mathrm{ha}^{-1}$ at a Western Australian site were measurable for at least 3 years after application; more 5 usual rates of lime application of $5 \mathrm{t} \mathrm{ha}^{-1}$ were not as effective.

Increases in soil moisture content due to liming are recognised in New Zealand but are considered minor and short lived (Wheeler and O'Connor 1988). During et al. (1984) observed increases of $4-8 \%$ units of soil moisture by weight on limed

10 compared with unlimed plots within 2 months on a New Zealand hill country soil and ascribed this to measured increases in aggregate stability associated with $\mathrm{Ca}$ addition. However, the authors noted that similar increases in soil moisture had not been observed at other sites. Lime application has been observed to

15 reduce penetrometer resistance in the surface $150-200 \mathrm{~mm}$ of a krasnozem in north-west Tasmania (Rowe and Johnson 1989). Rowe and Johnson (1995) rejected the hypothesis that the response to lime by barley was due to increased availability of soil water because water deficits were similar on limed and

20 unlimed plots at maturity in late January. Soil water deficit was higher in limed plots in the period early November-midDecember, probably due to higher crop biomass during this period. Steed et al. (1987) did not observe changes in soil strength or sorptivity due to lime treatment alone in an acid

25 soil in north-eastern Victoria, but did observe a large increase in sorptivity due to lime application when the soil had been deep ripped. Lime treatment did not increase water extraction by a wheat crop.

Lime application increased the abundance of earthworms in

30 an acid soil in southern NSW (White et al. 2000). This effect of lime could be expected to increase infiltration of water to plant roots and increase incorporation of lime. In New Zealand, earthworms have an additional benefit for drought survival of white clover by promoting soil turnover and burial of stolons,

35 protecting them from desiccation (Brock and Kim 1994).

The evidence presented supports the view of Wheeler and O'Connor (1988) that increases in soil moisture due to lime application are likely to be small. Further study is needed to determine whether these small differences could be beneficial to

40 white clover survival given conditions of highly restricted water storage due to shallow rooting depth.

A further consequence of restricted soil water storage for white clover is that large herbage growth responses to lime application when moisture availability is high could reduce

45 plant survival because of rapid exhaustion of soil moisture under a subsequent dry spell. In theory this appears possible because cumulative water use is closely related to cumulative herbage yield (Singh and Sale 2000; Brown et al. 2005), but may depend on whether: (1) increased herbage growth under moist

50 conditions is accompanied by greater root exploration; (2) the additional growth is grazed, reducing transpiration later in the season when the soil is drier; and (3) the onset of drought stress is gradual enough for plant mechanisms to respond. In addition, lime application may improve plant resistance to drought through

55 improved mineral nutrition, such as that observed at high versus low P status (Singh et al. 1997; Singh and Sale 2000).

Root growth of white clover can increase under drought stress if there is time for plants to adjust. Annicchiarico and Piano (2004) observed increases in root dry weight under drought stress compared with the absence of stress over a 4- to 5-month period of $24 \%$ in the $10-230 \mathrm{~mm}$ layer, $45 \%$ in the $240-260 \mathrm{~mm}$ layer and $88 \%$ in the $470-690 \mathrm{~mm}$ layer in a sandy loam soil. However, only $4-5 \%$ of root mass was in the deepest layer and two-thirds of the increase in root mass occurred in 10-230 mm layer. Nevertheless, small increases in root access to moisture may aid stolon survival during drought. In some circumstances it appears that white clover can dry soil as deep as perennial grasses. For example, Karsten and MacAdam (2001) showed that white clover grown separately in tubes had much smaller root systems than perennial ryegrass and tall fescue, but had some roots at depths to $900 \mathrm{~mm}$ and dried the soil equally to the grasses to this depth during a drought period, although more slowly. Presumably white clover would be disadvantaged if grown with the grasses in a marginally dry environment.

\section{Soil carbon and water-holding capacity}

There are several reports of long-term fertiliser application resulting in increased water-stable aggregation, porosity, infiltration capacity and hydraulic conductivity, and decreases in bulk density (Haynes and Naidu 1998), all factors that would favour increased plant-available water in the field. Applications of manures can also result in increased soil organic matter content, leading to similar improvements in soil physical condition and hydraulic properties (Haynes and Naidu 1998), with even low application rates leading to small but significant increases in plant-available water in the field (Hayes et al. 2017). The effects of lime, fertiliser and manure applications on soil can be complex, with many interactions possible, some of which have potential negative consequences for plant-available water. For example, high application rates of manure risk the accumulation of $\mathrm{K}^{+}, \mathrm{Na}^{+}$and $\mathrm{NH}_{4}^{+}$in the soil, resulting in dispersion of clay particles and the production of waterrepellent substances by decomposer fungi (Haynes and Naidu 1998).

Increasing soil organic carbon (SOC) has been associated with superphosphate application and the associated increase in biomass production and $\mathrm{N}$ fixation from legumes (Donald and Williams 1954; Chan et al. 2010). Periodic excesses of available $\mathrm{N}$ from legume residues as well as $\mathrm{P}$ and $\mathrm{S}$ from superphosphate application likely stimulate $\mathrm{C}$ sequestration in soils because all three elements are known to be fundamental to the formation and retention of stable or 'humic-derived' SOC (Kirkby et al. 2011). Other common management actions, such as sowing improved pasture and improved grazing management, have not demonstrated the same increase in soil carbon as increased soil fertility (Orgill et al. 2014). Often the associated increase in clover has resulted in a decrease in soil $\mathrm{pH}$ that needs to be managed with lime application (Williams 1980).

\section{Role of macronutrients in the growth, development and persistence of legumes}

\section{Phosphorus}

Soil $\mathrm{P}$ fertility is a significant factor limiting pasture productivity in south-eastern Australia (Begg 1963; Helyar and Anderson 1970). This is attributed to the low concentrations of available $\mathrm{P}$ in many soils used for pasture production, and the relatively high critical external requirement 
for $\mathrm{P}$ (i.e. soil test $\mathrm{P}$ concentration required to reach $90 \%$ or $95 \%$ of maximum yield) of these mixed grass-legume systems. Optimum soil $\mathrm{P}$ fertility management is currently achieved when soil test $\mathrm{P}$ concentrations are maintained close to the 5 critical P requirement of the legume (Reuter et al. 1995; Simpson et al. 2014, 2015). Cultivars that effectively maximise soil exploration by roots at low levels of available P have a lower critical external $P$ requirement. This is attributed to an ability to deploy a combination of high root length density (i.e.

10 root length per unit soil volume), high specific root length (i.e. root length per unit root mass) and long root hairs, particularly in the surface or topsoil layer, where P is most concentrated.

Among the perennial legume species that are adapted to south-eastern Australia, controlled-environment studies have 15 found the perennial legumes (lucerne, birdsfoot trefoil and Caucasian clover) to rank poor-intermediate in their nutrient foraging potential (Kidd et al. 2016; Yang et al. 2017). The effective soil exploration (determined as specific root hair cylinder; i.e. volume of soil encompassed by the root and root 20 hairs on a per unit root mass basis) of 6-week-old plants of these species was less than $20 \%$ that of phalaris and cocksfoot, which are commonly grown in mixtures with these species (Yang et al, 2017). White clover is also sensitive to low soil $\mathrm{P}$ supply and has root traits typical of other Trifolium species (e.g. relatively short root hairs; Caradus 1980).

There has been significant interest in characterising the intraspecific variation in nutrient foraging traits and/or response to P of white clover (Snaydon and Bradshaw 1962; Caradus 1979; Mackay et al. 1990; Caradus et al. 1995; Crush 30 et al. 2008). However, although significant genotype or cultivar variation has been found, these differences have not necessarily translated into genotypes that are productive at low soil P supply under field conditions (Caradus and Snaydon 1986a, 1986b, 1986c). This is likely due to a combination of factors, including

35 limited intraspecific variation in traits that confer $\mathrm{P}$ acquisition efficiency, lower yield potential of more 'P-efficient' genotypes, screening methods for root traits (e.g. solution culture) confounding the potential variation in and value of root traits for $\mathrm{P}$ acquisition and other field-based factors affecting the

40 expression of phenotypes or adaptation of a genotype (e.g. edaphic constraints, grazing; Caradus and Snaydon 1986a, $1986 b, 1986 c)$. The potential to use interspecific hybridisation to improve the nutrient foraging traits and $\mathrm{P}$ acquisition efficiency in white clover has also been investigated, but 45 improvements in DM yield have been relatively limited (Nichols et al. 2014a, 2014b). Less work has been undertaken to characterise the intraspecific variation in nutrient foraging traits of lucerne, which appears to have a very high critical $\mathrm{P}$ requirement (Sandral et al. 2019).

There are many studies demonstrating the beneficial effect that $\mathrm{P}$ management has on DM production, legume abundance and $\mathrm{N}_{2}$ fixation of pasture legumes on soils in south-eastern Australia (Helyar and Anderson 1970; Brock 1973; Singh et al. 1999; Hogh-Jensen et al. 2002). However, there is less evidence

55 demonstrating the link between soil $\mathrm{P}$ fertility and the long-term persistence of perennial legumes. In a series of glasshouse experiments it was shown that improving soil $\mathrm{P}$ fertility improved the tolerance to drought and/or defoliation stress of white clover; high soil $\mathrm{P}$ was associated with greater coarse root length ( $>1 \mathrm{~mm}$ diameter), greater water extraction and an ability to maintain higher leaf water potential (Singh and Sale 1997, 1998, 2000; Singh et al. 1997). Moreover, compared with low soil $\mathrm{P}$, high soil $\mathrm{P}$ was found to improve the recovery of plants from water stress on rewatering (Singh et al. 2000). Phosphorus application was subsequently shown to improve the persistence of white clover in the field (Singh et al. 1999). However, the relationship between soil $\mathrm{P}$ fertility, productivity and/or persistence of a perennial legume in a mixed sward is likely to be dependent upon the combination of biotic (e.g. companion grasses, disease), abiotic (e.g. soil acidity, prevailing seasonal conditions) and management (e.g. grazing) factors present at a given site, and not soil $\mathrm{P}$ fertility or P requirement of the genotype alone. Indeed, this has been shown to be the case in perennial pasture grasses; the persistence of phalaris was affected by a combination of grazing management, genotype and soil $\mathrm{P}$ fertility, with greater persistence under rotational grazing versus high continuous stocking, regardless of soil P supply, although $\mathrm{P}$ was still of benefit for persistence in a continuously stocked system (Culvenor and Simpson 2016). Furthermore, competition for resources by companion grasses (e.g. shading effects) can suppress the DM production and $\mathrm{N}_{2}$ fixation of legumes regardless of soil $\mathrm{P}$ availability (Jackman and Mouat 1972).

The interaction between soil $\mathrm{P}$ availability and drought is likely to be a particularly significant factor affecting the productivity and persistence of perennial legumes in southeastern Australia. Phosphorus supply to the root is largely driven by diffusion, and dry conditions temporarily reduce the quantity of available soil $\mathrm{P}$ and potentially exacerbate the effects of low soil P supply (Drew and Nye 1970; Mouat and Nes 1985; Pinkerton and Simpson 1986). This raises the question as to what is the root 'ideotype' for a persistent perennial pasture legume for south-eastern Australia. Successful perennial grasses in these systems deploy a combination of effective nutrient foraging traits in the topsoil and deep roots, and may also deploy other droughttolerance attributes (e.g. drought-induced summer dormancy; Culvenor and Simpson 2014). Legume species or genotypes that are more effective at topsoil foraging may have an advantage in terms of $\mathrm{P}$ acquisition in dry conditions, but not if this is to the detriment of achieving deep roots. White clover is recognised as being relatively shallow rooted, and significant efforts have been aimed at improving its drought tolerance through targeting root traits (e.g. Nichols et al. 2016), although it is not known whether the root traits for $\mathrm{P}$ acquisition efficiency and drought tolerance are complementary. In lucerne it has been shown that application of $\mathrm{P}$ to the topsoil results in an increase in root length density not only in the topsoil where $\mathrm{P}$ has been applied, but also to depth (Denton et al. 2006). It is therefore likely that improved $\mathrm{P}$ nutrition through $\mathrm{P}$ application and/or selection for improved nutrient foraging traits in the topsoil would have benefits due to an overall larger and deeper root system.

\section{Sulfur and potassium}

Soil $\mathrm{S}$ and $\mathrm{K}$ are other important macronutrients likely to affect perennial legume persistence during periodic drought. Unlike $\mathrm{P}$, where the occurrence of deficiency is almost universal across soils of the target region, $\mathrm{S}$ and $\mathrm{K}$ 
deficiencies are likely to be more localised. Diagnosis of S and K deficiencies based on soil tests alone is more problematic than for $\mathrm{P}$ on account of their solubility in the soil solution; thus, substantial quantities of $\mathrm{S}$ and $\mathrm{K}$ can be found in subsurface

5 layers of the soil profile, below the standard depth of soil testing (commonly to $100 \mathrm{~mm}$ ). Nevertheless, it is reasonable to anticipate substantial $\mathrm{S}$ and $\mathrm{K}$ deficiency in the surface soil layers, particularly in duplex soils or basalt-derived soils (for S only) across the vast target region of south-eastern Australia.

10 This will primarily be a constraint for shallow-rooted species such as white clover, which typically have reduced access to nutrients at depth.

To some extent, $\mathrm{S}$ deficiency has been traditionally managed in grazing systems through the ongoing application of single

15 superphosphate (typically $8.8 \% \mathrm{P}, 11 \% \mathrm{~S}$ ), despite $\mathrm{P}$ being the more limiting nutrient in most soils and the primary motivation for the widespread application of this fertiliser (Blair 2008). As such, there are relatively few reports of the effect of S deficiency in pasture legumes in Australia, because even in instances where

20 it has not been addressed by the application of single superphosphate, $\mathrm{P}$ deficiency commonly masks the effects of $\mathrm{S}$ deficiency. Nevertheless, regions do exist where $\mathrm{S}$ is a more limiting nutrient than $\mathrm{P}$, for example the basalt-derived soils of the Monaro region in southern NSW (McLachlan 1955;

25 McLachlan and De Marco 1968).

Sulfur is an essential nutrient required by plants in relatively large quantities for protein synthesis and plant growth (Atwell et al. 2001). Therefore, the primary effect of S deficiency on drought survival mechanisms of legumes is reduced access to

30 water through constrained root growth. Sulfur deficiency constrains $\mathrm{N}$ fixation of legumes because it is an essential nutrient for functioning rhizobia required for the synthesis of vitamins and S-containing amino acids (O'Hara 2001).

Application of $\mathrm{K}$ fertilisers to non-irrigated pastures grazed

35 for meat and wool production is far less common in south-eastern Australia compared with $\mathrm{P}$ and $\mathrm{S}$ fertilisers. Although some earlier work was undertaken at particular locations throughout the target region to understand the K status of pastures at a point in time (e.g. Spencer and Govaars 1982), there has been relatively

40 little attention paid to $\mathrm{K}$ nutrition in permanent pastures other than to quantify $\mathrm{K}$ requirements of particular species, such as white clover (Andrew 1960; Andrew and Robins 1969), Because many decades have now passed since previous $\mathrm{K}$ nutrition in pasture studies were conducted, it seems a priority to revisit the

45 topic of $\mathrm{K}$ nutrition, because previous assessments may now be unreliable due to ongoing depletion of soil $\mathrm{K}$ during the intervening period and changed plant availability associated with changes in other soil characteristics, such as $\mathrm{pH}$. The nutritional status of land used for dairy is much better

50 understood, with several detailed soil surveys being undertaken recently (Gourley et al. 2012; Cotching et al. 2017). The use of $\mathrm{K}$ fertilisers in the higher-intensity dairy industry is more common than in more extensive grazing systems.

Potassium is required by plants for multiple functions, including activation of enzymes for photosynthesis, and in the synthesis of protein and starch. Importantly, $\mathrm{K}$ is also fundamental in the osmoregulation of plants, including stomatal control and the internal transport of sugars
(Armstrong 1998). The importance of $\mathrm{K}$ in plant cell structure was observed in winter cereals and canola by Holland et al. (2018), who recorded increased crop lodging (reduced stem strength) as soil $\mathrm{K}$ levels declined. It is not clear whether improved $\mathrm{K}$ nutrition would assist a profligate water user such as white clover to reduce water loss under drought stress, but a direct connection between $\mathrm{K}$ nutrition and legume response under drought must exist and has thus far received little attention. Potassium is also an essential nutrient for rhizobia in the activation of enzymes for protein synthesis (O'Hara et al. 1988). It may therefore be expected that legume persistence on K-deficient soils may be challenged directly by the reduced osmoregulation of affected plants and indirectly from reduced $\mathrm{N}$ supply associated with suboptimal biological $\mathrm{N}$ fixation.

Role of micronutrients in the growth, development and persistence of legumes

Legumes and rhizobia both require chlorine $(\mathrm{Cl})$, boron $(\mathrm{B})$, iron $(\mathrm{Fe}), \mathrm{Mn}$, zinc $(\mathrm{Zn})$, copper $(\mathrm{Cu})$, nickel $(\mathrm{Ni})$ and $\mathrm{Mo}$, with rhizobia additionally requiring cobalt $(\mathrm{Co})$ and selenium (Se; O'Hara et al. 1988; Marschner 2012). The role of micronutrients in ameliorating plant drought stress is not well elucidated (Waraich et al. 2011); however, it is likely that providing legumes and their associated rhizobia with a sufficient supply of micronutrients necessary for crucial plant and microbial processes will allow them to be more resilient in the face of environmental stresses.

The extent and magnitude of micronutrient deficiencies in plants across Australia is not well documented. This is largely due to the fact that deficiencies are typically associated with localised soil factors and because their availability can change temporally (e.g. with soil moisture or $\mathrm{pH}$ ). In addition, plants vary in their ability to access micronutrients from the soil, so although one species may show symptoms of deficiency in a particular nutrient, others may not. For these reasons, the presence of micronutrients is not generally tested in soils, but rather in plant tissue. Often, known soil factors are used to identify risk of micronutrient deficiency, such as $\mathrm{pH}$, with $\mathrm{B}$, $\mathrm{Co}, \mathrm{Cu}$ and $\mathrm{Zn}$ being most available at a $\mathrm{pH}$ of roughly 5.0-7.0 (Sanders 1983; Armour and Brennan 1999; Mengel 2001), and Mo at a pH of 5.0-6.0 and >8.0 (Sillanpää 1982). Other factors affecting the availability of particular micronutrients include the presence and form of other minerals that may affect uptake by plants, plant health factors (e.g. disease), which may also affect uptake, or simply by inherent plant traits, such as the critical requirement of a particular micronutrient, meaning that deficiency in a particular environment may be species specific. In these cases, the micronutrient is deficient in the plant, not the soil. In the case of white clover, which is renowned to have a shallow rooting depth, reported deficiency may simply reflect the fact that plant roots are too shallow to access micronutrients that may be abundant at depth.

Nevertheless, previous authors (see Fig. 2) have mapped the occurrence or risk of particular micronutrient deficiencies. These maps are inherently unreliable due to the vagaries described above in understanding whether a nutrient is truly deficient in soil or whether it is simply unavailable to a particular species of interest at the time of sampling. The maps are made less reliable 


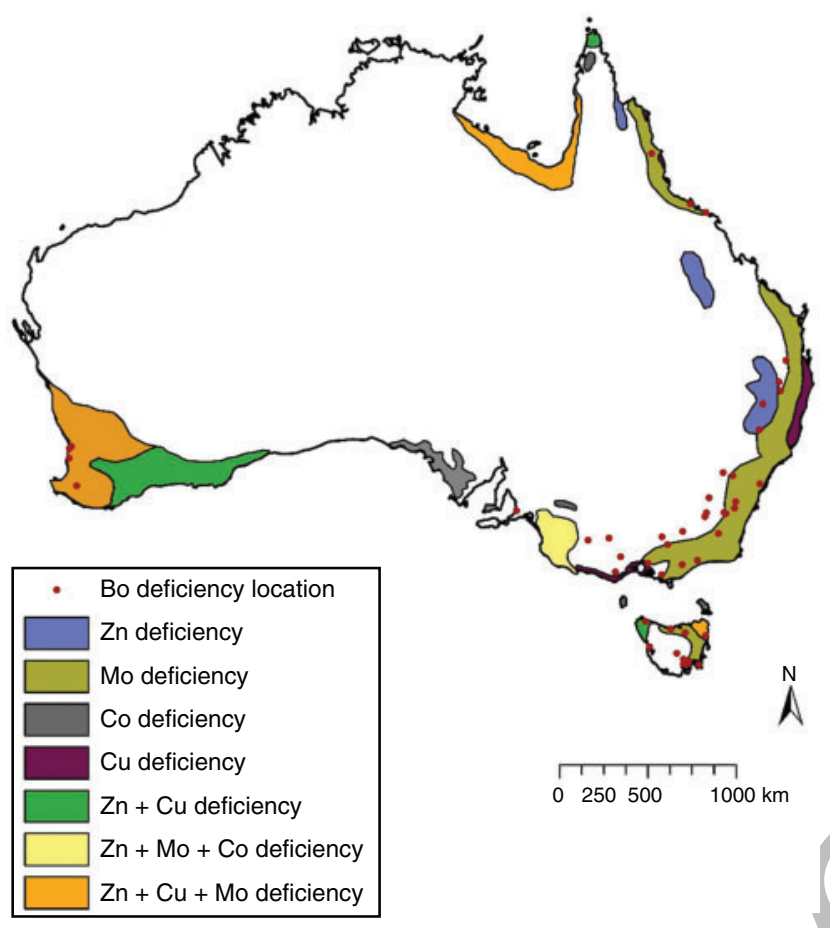

Fig. 2. A visual representation of perceived boron (B), zinc ( $\mathrm{Zn})$, molybdenum (Mo), cobalt $(\mathrm{Co})$ and copper $(\mathrm{Cu})$ deficiencies collated from maps and observations from multiple sources (Donald and Prescott 1975; Jackson and Chapman 1975; Hosking et al. 1986; Dear and Lipsett 1987; Judson and Reuter 1999; Peverill and Judson 1999; Wong et al. 2005; Hamilton et al. 2015).

by the significant period that has elapsed since the time they were initially constructed (generally pre-1980), allowing opportunity for significant changes to have occurred due to the ongoing depletion of nutrients since that time, advances in plant breeding 5 and new cultivars, or the inevitable change in availability due to soil acidification attributable to agricultural production. There is a pressing need to obtain a more comprehensive understanding of the soil-related risk of micronutrient deficiency in Australia, but, in the absence of better information, Fig. 2 shows the

10 approximate regions where a high risk of particular micronutrient deficiencies has previously been thought to exist for crops and pastures. In south-eastern Australia, deficiencies in $\mathrm{B}, \mathrm{Co}, \mathrm{Cu}, \mathrm{Mo}$ and $\mathrm{Zn}$ have traditionally been most limiting and therefore these micronutrients are of primary focus in this review.

\section{Boron deficiency}

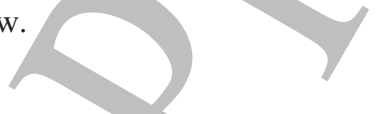

Boron has been shown to be important in plants in cell wall architecture through its complexation with pectins, osmotic adjustment, phenolic metabolism, oxidative stress and the

20 translocation of sugars (Brown et al. 2002; Marschner 2012). It has also been proposed to be important in pollen tube integrity, $\mathrm{N}$ metabolism and seed yield (Brown et al. 2002). In addition, B is critical for the legume-rhizobium symbiosis, because it is required for nod gene activation by root exudates (Redondo25 Nieto et al. 2001), nodule initiation, infection thread development and nodule invasion (Bolaños et al. 1996), as well as for regulation of rhizobial cell density (Chen et al. 2002).

Boron deficiency affects the ability of legumes to deal with drought conditions in several ways. First, B deficiency reduces root growth, which reduces the ability of plants to access soil water (Wimmer and Eichert 2013). Second, B deficiency affects the development and formation of vascular components such as the xylem (Dell and Huang 1997), which transports water and nutrients from roots to shoots, impeding translocation and internal osmoregulation. Third, there is evidence that stomatal function is affeeted by B deficiency, which leads to lower rates of transpiration, reduced photosynthesis and a reduced ability to adjust the stomatal aperture (Wimmer and Eichert 2013), which could lead to increased water loss under drought stress. In perennial species reliant upon recruitment of seedlings to persist longer term, B deficiency may also constrain seed production, as was demonstrated in subterranean clover (Dear and Lipsett 1987; Hamilton et al. 2015).

Boron deficiencies have been reported in subterranean clover in the Southern Tablelands of NSW (Dear and Lipsett 1987), in lucerne in north-east Victoria and East Gippsland and in pastures in the west Wimmera (Hosking et al. 1986) and on the Central Tablelands of NSW (Haddad and Kaldor 1982). In addition, B deficiency has been reported in forestry and horticultural industries, particularly in south-eastern Australia. The map developed by Jackson and Chapman (1975) depicting the locations of reported B deficiency across south-eastern Australia has been adapted and updated in Fig. 2.

\section{Cobalt}

Cobalt is not an essential micronutrient for plants, but is required by rhizobia for the coenzyme cobalamin (vitamin $\mathrm{B}_{12}$ ) involved in the synthesis of leghaemoglobin (Marschner 2012), which is important for providing oxygen for the functioning of nitrogenase (Becana et al. 2000). Apart from maintaining $\mathrm{N}$ fixation, cobalt is not known to aid in the drought resistance of legumes.

Cobalt deficiency is relatively localised in the target region of south-east Australia (Fig. 2). Deficiencies have been recorded on Kangaroo Island, South Australia (Lines 1935), Tasmania (Thain 1955), multiple parts of southern Victoria (Hosking et al. 1986) and in the Northern Tablelands of NSW (Duncan et al. 1986).

\section{Copper}

Copper has many important functions in plants. It is used in photosynthesis, for mitochondrial respiration, carbon and $\mathrm{N}$ metabolism, oxidative stress protection and cell wall synthesis (Hänsch and Mendel 2009).

The role of $\mathrm{Cu}$ in legume-rhizobia symbiosis is not clear, but it has been suggested to be involved in oxidation of phenolic compounds by rhizobia (Seliga 1998). Copper has several functions in plants under drought stress. Because copper is involved in the synthesis of lignin, sufficient copper nutrition improves the strength of the cell wall, preventing wilting when plants are under water stress (Waraich et al. 2011). Coppercontaining enzymes, such as ascorbate peroxidase, responsible for lignification, have been found to increase in white clover following water deficit (Lee et al. 2007). In addition, 
$\mathrm{Cu}$-containing genes such as $\mathrm{Cu} / \mathrm{Zn}$-superoxide dismutases, glutathione- $S$-transferase, copper chaperones and redox stressassociated genes, perform antioxidative functions under drought stress (Ma et al. 2015). Copper deficiency has been observed in 5 southern South Australia, northern Tasmania, eastern NSW (Donald and Prescott 1975) and in large areas of southern Victoria (Hosking et al. 1986).

\section{Molybdenum}

Molybdenum forms the basis of several important enzymes, and

10 in legumes specifically it forms the basis of nitrogenase, which is involved in the fixation of atmospheric $\mathrm{N}$ by rhizobia (Hoffman et al.2014), and xanthine dehydrogenase, which is integral to the mobilisation and exportation of fixed $\mathrm{N}$ from the nodule to the plant root (Kaiser et al.2005). One of the strategies used by plants

15 in response to drought stress is to close their stomata to reduce loss of water via transpiration (Osakabe et al. 2014). The closure of the stomata is induced by the accumulation of abscisic acid (ABA) in the leaf cells ( $\mathrm{Lu}$ et al. 2013), and because ABA synthesis is catalysed by the Mo-based enzyme aldehyde

20 oxidase, having adequate Mo is important for plants to be able to respond to drought stress. In addition, abiotic stresses, such as drought, can cause increased production of reactive oxygen species (ROS), which can damage plant cells (Miller et al. 2010). Xanthine dehydrogenase, another Mo-based

25 enzyme, scavenges ROS, reducing damage to cells. Molybdenum application to wheat has been shown to decrease the concentration of malondialdehyde, a marker of oxidative stress, leading to less damage from oxidative stress and increased DM and grain yield (Wu et al. 2014). It is likely that

30 adequate Mo nutrition of pasture legumes would also increase their tolerance to drought conditions by increasing their ability to scavenge ROS.

Because Mo is important for $\mathrm{N}$ nutrition in legumes, via the enzymes nitrogenase and nitrate reductase, it is also likely that

35 Mo deficiency would affect $\mathrm{N}$ availability, decreasing root and shoot growth and therefore the ability of the plant to access soil water. Responses to added Mo have been observed in subterranean clover and lucerne in South Australia (Anderson 1942, 1946), in lime-responsive ironstone soils in Tasmania

40 (Fricke 1943, 1944) and in lucerne and subterranean clover in the acid soils of the Tablelands of NSW (Shaw et al. 1944; Anderson and Moye 1952), and much of southern Victoria has been found to be low in Mo (Hosking et al. 1986). Donald and Prescott (1975) suggest that large swathes of the coastal regions

45 of south-east Australia and most of Tasmania's agricultural areas are likely to be Mo deficient (Fig. 2).

\section{Zinc}

Zinc plays a role as a functional, structural or regulatory cofactor of many plant enzymes (Brown et al. 1993), including zinc finger

50 proteins, which bind DNA, RNA, proteins and other molecules (Broadley et al. 2007). Zinc finger proteins have been found to be important for plant response to drought stress because they regulate the build-up of $\mathrm{H}_{2} \mathrm{O}_{2}$ in stomatal guard cells triggering stomatal closure, enhancing drought tolerance

55 (Huang et al. 2009). Zinc finger proteins have also been found to protect photosynthetic apparatus against ROS (Osakabe et al.
2014). Therefore, $\mathrm{Zn}$ deficiency may make plants more vulnerable from damage due to water stress, and less able to respond to rainfall following drought. Zinc is also required by rhizobia and is involved in carbonic anhydrase, which is important for root nodulation (Vance 2008), and is required for $\mathrm{N}$ fixation in the nodule, despite the fact that the role(s) of $\mathrm{Zn}$ in $\mathrm{N}$ fixation are not fully elucidated (León-Mediavilla et al. 2018). Zinc deficiency reduces root growth, and therefore reduces the ability of plants to access soil water when under water stress, and $\mathrm{Zn}$ deficiency was found to decrease water efficiency in chickpea (Cicer arietinium; Khan et al. 2004).

Zinc deficiencies have been reported in northern and eastern Tasmania, southern and eastern NSW and southern Victoria and South Australia (Donald and Prescott 1975), but $\mathrm{Zn}$ is generally not considered a constraint in many of the permanent pastures in the target region of south-eastern Australia (Fig. 2).

\section{Future opportunities}

Maximising the productivity of mixed pasture swards across the vast target region of south-eastern Australia will require higher and more consistent inputs of $\mathrm{N}$, which will likely only be achieved with greater legume biomass (Peoples et al. 2012). This is a challenging goal, particularly with future climate scenarios predicted to be generally warmer and more variable than in previous decades (Cullen et al. 2012). Perennial legumes offer advantages over annual legumes in being able to stabilise production (Kemp et al. 2002), use out-of-season rainfall (Sandral et al. 2006) and access water and nutrients from a greater volume of soil due to deeper and more permanent root systems (Ward et al. 2001). However, the paucity of adapted legume species available dictates that additional management is required to maximise the productivity and persistence of the commercially available species, particularly with regard to soil management. In the longer term, further plant breeding is required to make perennial legumes more resilient to periodic droughts.

\section{Increasing soil fertility}

There are various mechanisms at play that serve to increase plant access to water to alleviate moisture stress. These can be categorised either as factors leading to increased soil water availability, increased exploration of the soil volume by plant roots or increased osmoregulation and control of water loss from plants (Table 1). Many of these factors lead to only transient increases in access to water, and those increases may often be only small in magnitude. For this reason it is likely that farmers will need to address various aspects of soil fertility to maximise these mechanisms to achieve sufficient increases in access to soil water and persistence in a drought-sensitive species such as white clover.

Nevertheless, many of the improvements to soil fertility required for enhanced perennial legume persistence are already recommended in achieving resilient and productive pasture systems. Adequate $\mathrm{P}$ nutrition has been shown to enhance white clover response following drought, and has long been an essential ingredient to any productive pasturebased system. The periodic application of Mo-based single superphosphate was traditionally common practice to support 
legume function and growth, and this should be continued. The benefits of lime in ameliorating low $\mathrm{pH}$ soils are well understood, with lime being a crucial input to improving soil conditions for legume growth and persistence across much of the target region.

5 Soil nutrition factors that have received less previous attention but are likely to play an important role in enhancing legume persistence in the target region include the macronutrient $\mathrm{K}$, fundamental in various plant functions, including internal osmoregulation, and the trace element $\mathrm{B}$, also important in the

10 function of the plant vascular system and legume-rhizobia symbiosis. Research is required to demonstrate the likely magnitude of improvements to legume persistence offered by better $\mathrm{K}$ and $\mathrm{B}$ nutrition, and to demonstrate the likely impact across the target region given that not all soils will be deficient in

To date there are little experimental data demonstrating the improved persistence of white clover following the amendment of one or more of these soil constraints. Generating such data is a high priority for validation before farmers are encouraged to

20 invest in a potentially expensive soil management regime and is necessary in understanding the impact of improved soil management on the zone of adaptation of white clover. This review also highlights the need for a more current and complete understanding of the extent to which micronutrient deficiencies

25 exist across the target region and limit legume productivity. Previous attempts to map micronutrient deficiency across Australia are dated and inherently vague, and therefore of limited use in informing management practices.

\section{Perennial legume germplasm}

30 There are relatively few near-term prospects for novel droughttolerant perennial legume species being developed for the Australian market. It seems unlikely that the private sector will deliver new species to fill this niche due to the large expense involved, the high risk of failure and the relatively limited market potential in Australia. There is some prospect that the existing cultivars of novel species such as Caucasian and Talish clovers developed in conjunction with the Tasmanian Institute of Agricultural Research, as well as the birdsfoot trefoil cultivars developed in conjunction with the NSW Department of

40 Primary Industries (Real et al. 2012) may become more available to farmers. There is also reasonable prospect that the hybrid lines developed in New Zealand through interspecific crosses between white clover and other perennial Trifolium species (Williams 2014) may ultimately be commercialised and make their way to the Australian market. However, the potential of any of these options to improve the perennial legume resilience of mixed pasture swards in the high-rainfall permanent pasture region of south-eastern Australia remains unknown.

For white clover, which will remain the cornerstone of 50 perennial legume inclusion in mixed pastures on the tablelands of south-eastern Australia for the foreseeable future, we identify a significant opportunity to increase its resilience under moisture stress by focusing attention on its seed characteristics to better regenerate from seed following drought. Much of the previous breeding emphasis in this species has been to develop stronger root systems and increase stolon density to foster greater longevity, and existing cultivars such as
Grasslands Tribute and Trophy are products of that effort. However, as white clover is pushed to the drier margins, it seems inevitable that swards will encounter dry periods that even the most drought-tolerant cultivars cannot endure, highlighting the importance of regeneration from seed as a crucial insurance and recovery measure.

It is interesting that relatively little work has been done in this area largely due to the relatively low contribution to spring biomass that regenerating seedlings were recorded to make (Jones 1980; Archer and Robinson 1989). Part of the issue with regenerating white clover seedlings is that they commonly emerge too late, primarily in winter and spring, to amass spring biomass. It seems that for regeneration to be an effective strategy, seedlings need to emerge earlier (before winter), perhaps even on late summer rain. Indeed, earlieremerging seedlings are likely to also confer greater summer survival due to increased plant size when the summer drought commences (Jones 1980; Archer and Robinson 1989). Examining the hard seed characteristics of white clover could be a fruitful line of investigation to improve regeneration from seed. Traditional white clover cultivars have been shown to have a high level of hard seed. A survey conducted in 1981 of 27 pastures in the Northern Tablelands of NSW showed that the proportion of the white clover seed reserves that were hard (impermeable to water), sampled in autumn-early winter, exceeded 80\% (Archer and Rochester 1982). Compared with well-adapted subterranean clover cultivars (Taylor 2005), this is a much higher level of hard seed than is optimum and, apparently, a much slower rate of hard seed breakdown to achieve reliable regeneration on early autumn rains.

Much effort has been devoted in Australia over many decades to study hard seed characteristics of key annual legume species and develop cultivars with suitable traits to ensure ongoing regeneration across a range of environments (Taylor 2005). The hard seed characteristics of subterranean clover are of particular interest given the prevalence of this annual species across the target region. Although there are differences among cultivars, subterranean clover generally has lower levels of hard seed than other self-regenerating annual legumes commonly used. The cultivars of subterranean clover that are better suited to the target region (e.g. Goulburn, Leura and Denmark) tend to have lower initial levels of hard seed (Nichols et al. 2013), which undoubtedly increases their capacity to germinate following late summer-early autumn rains in these cooler environments. We postulate that a white clover ecotype with more similar hard seed characteristics to these subterranean clover cultivars would confer greater persistence in mixed pasture swards of the target region. White clover persistence would benefit from frequent rotational grazing, although further work is required to refine recommendations around grazing to maximise seed set.

\section{Conflicts of interest}

The authors declare no conflicts of interest.

\section{Acknowledgements}

Financial support for writing this review was through a project jointly funded by the NSW Department of Primary Industries and the Meat and Livestock 
Australia Donor Company under the Livestock Productivity Partnership, P. PSH.1030. The Tasmanian Institute of Agriculture and CSIRO also generously contributed the time of various staff to this review.

\section{References}

5 Abbott LK, Murphy DV (2007) 'Soil biological fertility - a key to sustainable land use in agriculture.' (Springer)

Anderson AJ (1942) Molybdenum deficiency on a South Australian ironstone soil. Journal of the Australian Institute of Agricultural Science 8, 73-75.

10 Anderson AJ (1946) Molybdenum in relation to pasture improvement in South Australia. Journal. Council for Scientific and Industrial Research (Australia) 9, 1-15.

Anderson AJ (1970) Trace elements for sheep pastures and fodder crops in Australia. Journal of the Australian Institute of Agricultural Science 36, $15-29$.

Anderson AJ, Moye DV (1952) Lime and molybdenum in clover development on acid soils. Australian Journal of Agricultural Research 3, 95-110. doi:10.1071/AR9520095

Andrew CS (1960) The effect of phosphorus, potassium, and calcium on the growth, chemical composition, and symptoms of deficiency of white clover in a subtropical environment. Australian Journal of Agricultural Research 11, 149-161. doi:10.1071/AR9600149

Andrew CS, Robins MF (1969) The effect of potassium on the growth and chemical composition of some tropical and temperate pasture legumes. I. Growth and critical percentages of potassium. Australian Journal of Agricultural Research 20, 999-1007. doi:10.1071/AR9690999

Annicchiarico P, Piano E (2004) Indirect selection for root development of white clover and implications for drought tolerance. Journal of Agronomy \& Crop Science 190, 28-34. doi:10.1046/j.0931-2250. 2003.00070.x

Aparicio-Tejo PM, Sanchez-Diaz MF, Pena JI (1980) Nitrogen fixation, stomatal response and transpiration in Medicago sativa, Trifolium repens and T. subterraneum under water stress and recovery. Physiologia Plantarum 48, 1-4. doi:10.1111/j.1399-3054.1980.tb03209.x

35 Archer KA, Gressor AJ (1979) 'White clover in New South Wales.' Plant Industry Bulletin P 2.5.10. (NSW Department of Agriculture: Sydney)

Archer KA, Robinson GG (1989) The role of stolons and seedlings in the persistence and production of white clover (Trifolium repens L. cv. Huia) in temperate pastures on the Northern Tablelands, New South Wales. Australian Journal of Agricultural Research 40, 605-616. doi:10.1071/ AR9890605

Archer KA, Rochester IJ (1982) Numbers and germination characteristics of white clover seed recovered from soils on the northern tablelands of New South Wales after drought. Journal of the Australian Institute of Agricultural Science 48, 99-101.

Armour JD, Brennan RF (1999) Zinc. In 'Soil analysis: an interpretation manual'. (Eds KI Peverill, DJ Reuter, LA Sparrow) (CSIRO Publishing: Melbourne)

Armstrong DL (1998) Potassium for Agriculture. Better Crops with Plant Food 82, 1-40.

Atwell BJ, Kriedmann PE, Turnbull CGN (2001) 'Plants in action - adaption in nature performance in cultivation.' (MacMillan Publishers: Melbourne)

Ayres JF, Caradus JR, Lane LA, Murison RD (1996) White clover breeding for dryland sheep and cattle pastures in Australia. In 'White clover: New Zealand's competitive edge'. Christchurch. (Ed. DR Woodfield) pp. 155-158. (Agronomy Society of New Zealand) https://www. grassland.org.nz/publications/nzgrassland_publication_643.pdf.

Ayres JF, Caradus JR, Murison RD, Lane LA, Woodfield DR (2007a) with tolerance of summer moisture stress. Australian Journal of Experimental Agriculture 47, 110-115. doi:10.1071/EA04029

Ayres JF, Kelman WM, Lane LA, McCorkell BE (2007b) Regeneration characteristics of birdsfoot trefoil (Lotus corniculatus L.) in low latitude environments in eastern Australia. Australian Journal of Experimental Agriculture 47, 833-843. doi:10.1071/EA06147

Ayres JF, Kelman WM, Wiedemann SG, Lane LA, McCorkell BE (2008) Developing birdsfoot trefoil (Lotus corniculatus L.) varieties for permanent pasture applications in low latitude regions of eastern Australia. Australian Journal of Experimental Agriculture 48, 488-498. doi:10.1071/EA07114

Ballard RA, Shepherd BR, Charman N (2003) Nodulation and growth of pasture legumes with naturalised soil rhizobia. 3. Lucerne (Medicago sativa L.). Australian Journal of Experimental Agriculture 43, 135-140. doi:10.1071/EA02047

Barker D, Caradus J, McManus M (1993) Physiological responses of white clover genotypes to water deficit. In 'Proceedings of the XVII International Grassland Congress'. Palmerston North, New Zealand. pp. 67-68. (New Zealand Grassland Association)

Barnet P (1991) Ecology of legume root nodule bacteria. In 'Biology ad biochemistry of nitrogen fixation'. (Eds MJ Dilworth, AR Glenn) pp. 199-228. (Elsevier: Amsterdam)

Becana M, Dalton DA, Moran JF, Iturbe-Ormaetxe I, Matamoros MA (2000) Reactive oxygen species and antioxidants in legume nodules Physiologia Plantarum 109, 372-381. doi:10.1034/j.1399-3054.2000. 100402.x

Begg JE (1963) Comparative responses of indigenous, naturalized, and commercial legumes to phosphorus and sulphur. Australian Journal of Experimental Agriculture and Animal Husbandry 3, 17-19. doi:10.1071/ EA9630017

Bell LW, Hayes RC, Pembleton KG, Waters CM (2014) Opportunities and challenges in Australian grasslands: pathways to achieve future sustainability and productivity imperatives. Crop and Pasture Science 65, 489-507. doi:10.1071/CP13420

Black AL, Brown PL, Halvorson AD, Siddoway FH (1981) Dryland cropping strategies for efficient water-use to control saline seeps in the Northern Great Plains, U.S.A. Agricultural Water Management 4, 295-311. doi:10.1016/0378-3774(81)90055-X

Black AD, Moot DJ, Lucas RJ (2006) Development and growth characteristics of Caucasian and white clover seedlings, compared with perennial ryegrass. Grass and Forage Science 61, 442-453. doi:10.1111/j.1365-2494.2006.00553.x

Blair G (2008) SSP: Single superphosphate, a scenario slowly passing. In 'Global Issues, Paddock Action. Proceedings of the 14th Australian Agronomy Conference'. 21-25 September, Adelaide, South Australia. (Ed. M Unkovich)

Bolaños L, Brewin NJ, Bonilla I (1996) Effects of boron on rhizobiumlegume cell-surface interactions and nodule development. Plant Physiology 110, 1249-1256. doi:10.1104/pp.110.4.1249

Bottomley PJ (1992) Ecology of Bradyrhizobium and Rhyzobium. In 'Biological nitrogen fixation'. (Eds G Stacey, RH Burris, HJ Evans) pp. 293-348. (Chapman and Hall: New York)

Bouton JH (1996) Screening the alfalfa core collection for acid soil tolerance. Crop Science 36, 198-200. doi:10.2135/cropsci1996.0011183X003 $600010035 \mathrm{x}$

Broadley MR, White PJ, Hammond JP, Zelko I, Lux A (2007) Zinc in plants. New Phytologist 173, 677-702. doi:10.1111/j.1469-8137.2007. 01996.x

Brock JL (1973) Growth and nitrogen fixation of pure stands of three pasture legumes with high/low phosphate. New Zealand Journal of Agricultural Research 16, 483-491. doi:10.1080/00288233.1973. 10421093

Brock JL, Kim MC (1994) Influence of the stolon/soil interface and plant morphology on the survival of white clover during severe drought. Proceedings of the New Zealand Grassland Association 56, 187-191.

Brockwell J, Bottomley PJ, Thies JE (1995) Manipulation of rhizobia microflora for improving legume productivity and soil fertility: A 
critical assessment. Plant and Soil 174, 143-180. doi:10.1007/ BF00032245

Brown PH, Cakmak I, Zhang Q (1993) Form and Function of Zinc Plants. In 'Proceedings of the International Symposium on Zinc in Soils and Plants'. The University of Western Australia, 27-28 September 1993. (Ed. AD Robson) pp. 93-106. (Springer: Dordrecht, The Netherlands)

Brown PH, Bellaloui N, Wimmer MA, Bassil ES, Ruiz J, Hu H, Pfeffer H, Dannel F, Romheld V (2002) Boron in plant biology. Plant Biology 4, 205-223. doi: $10.1055 / \mathrm{s}-2002-25740$

10 Brown HE, Moot DJ, Pollock KM (2005) Herbage production, persistence, nutritive characteristics and water use of perennial forages grown over 6 years on a Wakanui silt loam. New Zealand Journal of Agricultural Research 48, 423-439. doi:10.1080/00288233.2005.9513677

Caradus JR (1979) Selection for root hair length in white clover (Trifolium repens L.). Euphytica 28, 489-494. doi:10.1007/BF00056609

Caradus JR (1980) Distinguishing between grass and legume species for efficiency of phosphorus use. New Zealand Journal of Agricultural Research 23, 75-81. doi:10.1080/00288233.1980.10417847

Caradus JR (1990) The structure and function of white clover root systems. Advances in Agronomy 43, 1-46. doi:10.1016/S0065-2113(08)60475-7

Caradus JR (1991) White clover improvement - a global perspective. In 'White Clover Workshop'. (Ed. N McFarlane) (Agriculture Victoria: Melbourne)

Caradus JR, Snaydon RW (1986a) Response to phosphorus of populations of white clover. 3. Comparison of experimental-techniques. New Zealand Journal of Agricultural Research 29, 169-178. doi:10.1080/00288233. 1986.10426970

Caradus JR, Snaydon RW (1986b) Response to phosphorus of populations of white clover. 2. Glasshouse and growth cabinet studies. New Zealand Journal of Agricultural Research 29, 163-168. doi:10.1080/00288233. 1986.10426969

Caradus JR, Snaydon RW (1986c) Response to phosphorus of populations of white clover. 1. Field studies. New Zealand Journal of Agricultural Research 29, 155-162. doi:10.1080/00288233.1986.10426968

35 Caradus JR, van den Bosch J, Woodfield DR, Mackay AC (1991) Performance of white clover cultivars and breeding lines in a mixed species sward. 1. Yield and clover content. New Zealand Journal of Agricultural Research 34, 141-154. doi:10.1080/00288233.1991. 10423353

40 Caradus JR, Mackay AD, Dunlop J, van den Bosch J (1995) Relationships between shoot and root characteristics of white clover cultivars differing in response to phosphorus. Journal of Plant Nutrition 18, 2707-2722. doi:10.1080/01904169509365095

Chan KY, Oates A, Li GD, Conyers MK, Prangnell RJ, Liu DL, Barchia IM (2010) Soil carbon stocks under different pastures and pasture management in the higher rainfall areas of south-eastern Australia. Australian Journal of Soil Research 48, 7-15. doi:10.1071/SR09092

Chatel DL, Parker CA (1973) The colonization of host-root and soil by Rhizobia-I. Species and strain differences in the field. Soil Biology \& Biochemistry 5, 425-432. doi:10.1016/0038-0717(73)90069-2

Chen X, Schauder S, Potier N, Van Dorsselaer A, Pelczer I, Bassler BL, Hughson FM (2002) Structural identification of a bacterial quorumsensing signal containing boron. Nature 415, 545-549. doi:10.1038/ $415545 \mathrm{a}$

55 Cotching WE, Taylor L, Findlay S, Davies P, Bennett S, Brown R (2017) Soil nutrient concentrations and farm gate nutrient balances for dairy farm management in Tasmania AU - Cotching, W. E. New Zealand Journal of Agricultural Research 60, 216-221. doi:10.1080/00288233.2017. 1295391

60 Coventry DR, Hirth JR, Reeves TG, Burnett VF (1985) Growth and nitrogen fixation by subterranean clover in response to inoculation, molybdenum application and soil amendment with lime. Soil Biology \& Biochemistry 17, 791-796. doi:10.1016/0038-0717(85) 90134-8
Crush JR, Boulesteix-Coutelier ARL, Ouyang L (2008) Phosphate uptake by white clover (Trifolium repens L.) genotypes with contrasting root morphology. New Zealand Journal of Agricultural Research 51, 279-285. doi:10.1080/00288230809510458

Cullen BR, Eckard RJ, Rawnsley RP (2012) Resistance of pasture production to projected climate changes in south-eastern Australia. Crop \& Pasture Science 63, 77-86. doi:10.1071/CP11274

Culvenor RA, Simpson RJ (2014) Persistence traits in perennial pasture grasses: the case of phalaris (Phalaris aquatica L.). Crop \& Pasture Science 65, 1165-1176. doi:10.1071/CP13333

Culvenor RA, Simpson RJ (2016) Interaction of plant genotype and management in the persistence of a perennial grass exposed to grazing and soil fertility stresses. Grass and Forage Science 71, 540-558. doi: $10.1111 /$ gfs. 12198

Curll ML (1987) Screening and evaluation of pasture species mixtures for northern New South Wales. In 'Temperate pastures: their production, use and management'. (Eds JL Wheeler, CJ Pearson, GE Robards) pp. 287-289. (CSIRO: Australia)

Curll ML, Jones RM (1989) The plant-animal interface and legume persistence - an Australian perspective. In 'Persistence of forage legumes'. (Eds GC Marten, AG Matches, RF Barnes, RW Brougham, RJClements, GW Sheath) pp. 339-359. (American Society of Agronomy Inc.: Madison, WI, USA)

Curll ML, Wilkins RJ (1981) Effects of treading and the return of excreta on a perennial ryegrass-white clover sward defoliated by continuous sheep grazing. In 'XIV International Grassland Congress'. Lexington, Kentucky, USA. (Eds JAS Smith, VW Hays) pp. 456-458. (West Press: Boulder, CO, USA)

Curll ML, Wilkins RJ (1982) Frequency and Severity of Defoliation of Grass and Clover by Sheep at Different Stocking Rates. Grass and Forage Science 37, 291-297. doi:10.1111/j.1365-2494.1982.tb01609.x

Curll ML, Wilkins RJ (1985) The Effect of Cutting for Conservation on a Grazed Perennial Ryegrass White Clover Pasture. Grass and Forage Science 40, 19-30. doi:10.1111/j.1365-2494.1985.tb01716.x

Dear BS, Lipsett J (1987) The effect of boron supply on the growth and seed production of subterranean clover (Trifolium subterraneum L.). Australian Journal of Agricultural Research 38, 537-546. doi:10.1071/ AR9870537

Dear BS, Zorin M (1985) Persistence and productivity of Trifolium ambiguum M. Bieb. (Caucasian clover) in a high altitude region of south-eastern Australia. Australian Journal of Experimental Agriculture 25, 124-132. doi:10.1071/EA9850124

Dear BS, Cocks PS, Wolfe EC, Collins DP (1998) Established perennial grasses reduce the growth of emerging subterranean clover seedlings through competition for water, light, and nutrients. Australian Journal of Agricultural Research 49, 41-52. doi:10.1071/A97062

Dear BS, Peoples MB, Cocks PS, Swan AD, Smith AB (1999) Nitrogen fixation by subterranean clover (Trifolium subterraneum L.) growing in pure culture and in mixtures with varying densities of lucerne (Medicago sativa L.) or phalaris (Phalaris aquatica L.). Australian Journal of Agricultural Research 50, 1047-1058. doi:10.1071/AR98186

Dear BS, Moore GA, Hughes SJ (2003) Adaptation and potential contribution of temperate perennial legumes to the southern Australian wheatbelt: a review. Australian Journal of Experimental Agriculture 43, 1-18. doi:10.1071/EA01202

Dell B, Huang L (1997) Physiological response of plants to low boron. Plant and Soil 193, 103-120. doi:10.1023/A:1004264009230

Denton MD, Sasse C, Tibbett M, Ryan MH (2006) Root distributions of Australian herbaceous perennial legumes in response to phosphorus placement. Functional Plant Biology 33, 1091-1102. doi:10.1071/ FP06176

Department of Health and Ageing (2004) The biology and ecology of white clover (Trifolium repens L.) in Australia. Report for the Office of the Gene Technology Regulator. Department of Health and Ageing, 
Commonwealth Government of Australia. Available at: http://www. ogtr.gov.au/internet/ogtr/publishing.nsf/content/clover-3/\$FILE/ biologywclover2.pdf.

Dilworth MJ, Tiwari RP, Reeve WG, Glenn AR (2000) Legume root nodule bacteria and acid pH. Science Progress 83, 357-389.

Divito GA, Sadras VO (2014) How do phosphorus, potassium and sulphur affect plant growth and biological nitrogen fixation in crop and pasture legumes? A meta-analysis. Field Crops Research 156, 161-171. doi:10.1016/j.fcr.2013.11.004

10 Donald CM, Prescott JA (1975) Trace elements in Australian crop and pasture production, 1924-1974. In 'Trace elements in soil-plant-animal systems'. (Eds DJD Nicholas, AH Egan) pp. 7-37. (Academic Press)

Donald CM, Williams CH (1954) Fertility and productivity of a podzolic soil as influenced by subterranean clover (Trifolium subterraneum L.) and superphosphate. Australian Journal of Agricultural Research 5, 664-687. doi:10.1071/AR9540664

Drew MC, Nye PH (1970) The supply of nutrient ions by diffusion to plant roots in soil: III. Uptake of phosphate by roots of onion, leek, and ryegrass. Plant and Soil 33, 545-563. doi:10.1007/BF01378245

20 Duncan IF, Greentree PL, Ellis KJ (1986) Cobalt deficiency in cattle. Australian Veterinary Journal 63, 127-128. doi:10.1111/j.1751-0813. 1986.tb07683.x

During C, Jackson BLJ, Dyson CB (1984) Lime effects on hill country. 1. Effect of lime and monocalcium phosphate on soil moisture. New Zealand Journal of Agricultural Research 27, 383-387. doi:10.1080/ 00288233.1984.10430639

Edmeades DC, Smart CE, Wheeler DM (1983) Aluminium toxicity in New Zealand soils: Preliminary results on the development of diagnostic criteria. New Zealand Journal of Agricultural Research 26, 493-501. doi:10.1080/00288233.1983.10427027

Evans J, Hochman Z, O'Connor GE, Osborne GJ (1988) Soil acidity and Rhizobium: their effects on nodulation of subterranean clover on the slopes of southern New South Wales. Australian Journal of Agricultural Research 39, 605-618. doi:10.1071/AR9880605

35 Evans J, Dear B, O'Connor GE (1990) Influence of an acid soil on the herbage yield and nodulation of five annual pasture legumes. Australian Journal of Experimental Agriculture 30, 55-60. doi:10.1071/EA9900055

Fricke EF (1943) Pastre establishment on ironstone soil at Cressy, molybdenum deficiency. Tasmanian Journal of Agriculture 14, 69-73.

40 Fricke EF (1944) Molybdenum deficiency. Tasmanian Journal of Agriculture 15, 65-70.

Genrich KC, Sheaffer CC, Ehlke NJ (1998) Kura clover growth and development during the seeding year. Crop Science 38, 735-741. doi:10.2135/cropsci1998.0011183X003800030020x

45 Giller KE (2001) 'Nitrogen fixation in tropical cropping systems.' (CABI Publishing: Wallingford, UK)

Gourley CJP, Dougherty WJ, Weaver DM, Aarons SR, Awty IM, Gibson DM, Hannah MC, Smith AP, Peverill KI (2012) Farm-scale nitrogen, phosphorus, potassium and sulfur balances and use efficiencies on Australian dairy farms. Animal Production Science 52, 929-944. doi:10.1071/AN11337

Graham PH, Vance CP (2003) Legumes: importance and constraints to greater use. Plant Physiology 131, 872-877. doi:10.1104/pp.017004

Hackney BF, Jenkins AJ, Powells J, Edwards CE, De Meyer S, Howieson JG, Yates RJ, Orgill SE (2019) Increased emphasis on soil management for improved pasture legume productivity. Crop \& Pasture Science 70, xxx.

Haddad KS, Kaldor CJ (1982) Effect of parent material, natural available soil boron, and applied boron and lime on the growth and chemical composition of lucerne on some acidic soils of the Central Tablelands of New South Wales. Australian Journal of Experimental Agriculture 22, 317-323. doi:10.1071/EA9820317

Hall EJ, Hughes SJ, Humphries AW, Corkrey R (2013) Habitat and plant diversity of Trifolium tumens (Steven ex M. Bieb.) collected in
Azerbaijan and its characterisation and field evaluation in Tasmania, Australia. Crop \& Pasture Science 64, 374-387. doi:10.1071/CP13040 Hamilton LJ, Reed KFM, Leach EMA, Brockwell J (2015) Boron deficiency in pasture based on subterranean clover (Trifolium subterraneum L.) is linked to symbiotic malfunction. Crop \& Pasture Science 66, 1197-1212. doi: $10.1071 / \mathrm{CP} 14300$

Hänsch R, Mendel RR (2009) Physiological functions of mineral micronutrients $(\mathrm{Cu}, \mathrm{Zn}, \mathrm{Mn}, \mathrm{Fe}, \mathrm{Ni}, \mathrm{Mo}, \mathrm{B}, \mathrm{Cl})$. Current Opinion in Plant Biology 12, 259-266. doi:10.1016/j.pbi.2009.05.006

Harris W (1987) Population dynamics and competition. In 'White clover'. (Eds MJ Baker, WM Williams) pp. 203-278. (CAB International: Wallingford, UK)

Hayes RC, Dear BS, Orchard BA, Eberbach P (2008) Benefits of smallseeded annual pasture legumes in pasture mixtures for variable environments. In 'Global Issues, Paddock Action. Proceedings of the 14th Australian Society of Agronomy Conference'. Adelaide, South Australia. (Ed. M Unkovich) Available at: http://www. agronomyaustraliaproceedings.org/

Hayes RC, Li GD, Dear BS, Conyers MK, Virgona JM (2010) Phalaris and lime - improving productivity on an acidic soil in a drought-prone 'highrainfall' environment. In 'Food Security from Sustainable Agriculture. Proceedings of 15th Agronomy Conference'. Lincoln, New Zealand. (Eds H Dove, RA Culvenor) (Australian Society of Agronomy)

Hayes RC, Scott BJ, Dear BS, Li GD, Auricht GC (2011) Seedling validation of acid soil tolerance of lucerne populations selected in solution culture high in aluminium. Crop \& Pasture Science 62, 803-811. doi:10.1071/ CP11093

Hayes RC, Conyers MK, Li GD, Poile GJ, Price A, McVittie BJ, Gardner MJ, Sandral GA, McCormick JI (2012) Spatial and temporal variation in soil $\mathrm{Mn}^{2+}$ concentrations and the impact of manganese toxicity on lucerne and subterranean clover seedlings. Crop \& Pasture Science 63, 875-885. doi: $10.1071 / \mathrm{CP} 12138$

Hayes RC, Li GD, Conyers MK, Virgona JM, Dear BS (2016) Lime increases productivity and the capacity of lucerne (Medicago sativa L.) and phalaris (Phalaris aquatica L.) to utilise stored soil water on an acidic soil in south-eastern Australia. Plant and Soil 400, 29-43. doi:10.1007/ s11104-015-2706-Z

Hayes RC, McCormick JI, Oates AA, Poile GJ, Conyers MK, Gardner MJ, Price A, O'Keeffe P, Li GD (2017) Addressing biophysical constraints for Australian farmers applying low rates of composted dairy waste to soil. Renewable Agriculture and Food Systems 33, 179-193.

Haynes RJ, Naidu R (1998) Influence of lime, fertilizer and manure applications on soil organic matter content and soil physical conditions: a review. Nutrient Cycling in Agroecosystems 51, 123-137. doi:10.1023/A:1009738307837

Helyar KR, Anderson AJ (1970) Responses of five pasture species to phosphorus, lime and nitrogen on an infertile acid soil with a high phosphate sorption capacity. Australian Journal of Agricultural Research 21, 677-692. doi:10.1071/AR9700677

Hill MJ (1996) Defining the white clover zone in eastern mainland Australia using a model and a geographic information system. Ecological Modelling 86, 245-252. doi:10.1016/0304-3800(95)00059-3

Hill MJ, Donald GE (1998) Australian temperate pastures database. CDROM. National Pastures Improved Coordinating Committee/CSIRO Division of Animal Production.

Hoffman BM, Lukoyanov D, Yang ZY, Dean DR, Seefeldt LC (2014) Mechanism of nitrogen fixation by nitrogenase: the next stage. Chemical Reviews 114, 4041-4062. doi:10.1021/cr400641x

Hogh-Jensen H, Schjoerring JK, Soussana JF (2002) The influence of phosphorus deficiency on growth and nitrogen fixation of white clover plants. Annals of Botany 90, 745-753. doi:10.1093/aob/mcf260

Holland JE, Hayes RC, Refshauge G, Poile GJ, Newell MT, Conyers MK (2018) Biomass, feed quality, mineral concentration and grain yield 
responses to potassium fertiliser of dual-purpose crops. New Zealand Journal of Agricultural Research 62, 476-494.

Horst WJ, Wang Y, Eticha D (2010) The role of the root apoplast in aluminium-induced inhibition of root elongation and in aluminium resistance of plants: a review. Annals of Botany 106, 185-197. doi: $10.1093 / \mathrm{aob} / \mathrm{mcq} 053$

Hosking WJ, Caple IW, Haplin CG, Brown AJ, Paynter DI, Conley DN, North-Coombes PL (1986) 'Trace elements for pastures and animals in Victoria.' (Department of Agriculture and Rural Affairs Melbourne Victoria Australia: Melbourne, Australia)

Howieson JG, Ewing MA (1986) Acid tolerance in the Rhizobium meliloti Medicago symbiosis. Australian Journal of Agricultural Research 37, 55-64. doi:10.1071/AR9860055

Howieson JG, Ewing MA, D'Antuono MF (1988) Selection for acid tolerance in Rhizobium meliloti. Plant and Soil 105, 179-188. doi:10.1007/BF02376781

Huang XY, Chao DY, Gao JP, Zhu MZ, Shi M, Lin HX (2009) A previously unknown zinc finger protein, DST, regulates drought and salt tolerance in rice via stomatal aperture control. Genes \& Development 23, 1805-1817. doi: $10.1101 / \mathrm{gad} .1812409$

Hutchinson K, King K, Wilkinson D (1995) Effects of rainfall, moisture stress, and stocking rate on the persistence of white clover over 30 years. Australian Journal of Experimental Agriculture 35, 1039-1047. doi:10.1071/EA9951039

25 Irwin JAG, Lloyd DL, Lowe KF (2001) Lucerne biology and genetic improvement - an analysis of past activities and future goals in Australia. Australian Journal of Agricultural Research 52, 699-712. doi:10.1071/AR00181

Jackman RH, Mouat MCH (1972) Competition between grass and clover for phosphate. 1. Effect of browntop (Agrostis tenuis Sibth) on white clover (Trifolium repens L.) growth and nitrogen fixation. New Zealand Journal of Agricultural Research 15, 653-666. doi:10.1080/00288233.1972. 10421622

Jackson JF, Chapman KSR (1975) The role of boron in plants. In 'Trace elements in soil-plant-animal systems'. (Eds DJD Nicholas, AH Egan) pp. 213-225. (Academic Press)

Jahufer MZZ, Clements R, Durant R, Woodfield DR (2009) Evaluation of white clover (Trifolium repens L.) commercial cultivars and experimental synthetics in south-west Victoria, Australia. New Zealand Journal of Agricultural Research 52, 407-415. doi:10.1080 00288230909510523

Jahufer MZZ, Ford JL, Widdup KH, Harris C, Cousins G, Ayres JF, Lane LA, Hofmann RW, Ballizany WL, Mercer CF, Crush JR, Williams WM, Woodfield DR, Barrett BA (2012) Improving white clover for Australasia. Crop and Pasture Science 63, 739-745. doi:10.1071/CP12142

Johns GG (1978) Transpirational, leaf area, stomatal and photosynthetic responses to gradually induced water stress in four temperate herbage species. Australian Journal of Plant Physiology 5, 113-125.

Jones RM (1980) Survival of seedlings and primary taproots of white clover (Trifolium repens) in subtropical pastures in south-east Queensland. Tropical Grasslands 14, 19-21.

Judson GJ, Reuter DJ (1999) Selenium. In 'Soil analysis: an interpretation manual'. (Eds KI Peverill, DJ Reuter, LA Sparrow) (CSIRO Publishing: Melbourne)

55 Kaiser BN, Gridley KL, Brady JN, Phillips T, Tyerman SD (2005) The role of molybdenum in agricultural plant production. Annals of Botany 96, 745-754. doi:10.1093/aob/mci226

Karsten HD, MacAdam JW (2001) Effect of drought on growth, carbohydrates, and soil water use by perennial ryegrass, tall fescue and white clover. Crop Science 41, 156-166. doi:10.2135/ cropsci2001.411156x

Kemp DR, Michalk DL, Goodacre M (2002) Productivity of pasture legumes and chicory in central New South Wales. Australian Journal of Experimental Agriculture 42, 15-25. doi:10.1071/EA98171
Khairo SA, Norton MR, Garden D, Graham P, Langford C, Armstrong P, Brassil $T$ (2010) The profitability of wool production after surface application of lime and superphosphate on acid soils. AFBM Journal 7, 1-10.

Khan HR, McDonald GK, Rengel Z (2004) Zinc fertilization and water stress affects plant water relations, stomatal conductance and osmotic adjustment in chickpea (Cicer arientinum L.). Plant and Soil 267, 271-284. doi:10.1007/s11104-005-0120-7

Kidd DR, Ryan MH, Haling RE, Lambers H, Sandral GA, Yang ZJ, Culvenor RA, Cawthray GR, Stefanski A, Simpson RJ (2016) Rhizosphere carboxylates and morphological root traits in pasture legumes and grasses. Plant and Soil 402, 77-89. doi:10.1007/s11104-015-2770-4

Kirkby CA, Kirkegaard JA, Richardson AE, Wade LJ, Blanchard C, Batten G (2011) Stable soil organic matter: A comparison of C:N:P:S ratios in Australian and other world soils. Geoderma 163,197-208. doi:10.1016/j. geoderma.2011.04.010

Kochian LV, Piñeros MA, Hoekenga OA (2005) The physiology, genetics and molecular biology of plant aluminum resistance and toxicity. Plant and Soil 274, 175-195. doi:10.1007/s11104-004-1158-7

Lane LA, Ayres JF, Lovett JV (1997) A review of the introduction and use of white clover (Trifolium repens L.) in Australia - significance for breeding objectives. Australian Journal of Experimental Agriculture 37, 831-839. doi:10.1071/EA97044

Lane LA, Ayres JF, Lovett JV (2000) The pastoral significance, adaptive characteristics, and grazing value of white clover (Trifolium repens L.) in dryland environments in Australia: a review. Australian Journal of Experimental Agriculture 40, 1033-1046. doi:10.1071/EA99141

Latta RA, Blacklow LJ, Cocks PS (2001) Comparative soil water, pasture production, and crop yields in phase farming systems with lucerne and annual pasture in Western Australia. Australian Journal of Agricultural Research 52, 295-303. doi:10.1071/AR99168

Lee BR, Kim KY, Jung WJ, Avice JC, Ourry A, Kim TH (2007) Peroxidases and lignification in relation to the intensity of water-deficit stress in white clover (Trifolium repens L.). Journal of Experimental Botany 58, 1271-1279. doi:10.1093/jxb/erl280

Leigh JH, Holgate MD (1978) Effects of pasture availability on the composition and quality of the diet selected by sheep grazing native, degenerate and improved pastures in the Upper Shoalhaven Valley, New South Wales. Australian Journal of Experimental Agriculture and Animal Husbandry 18, 381-390. doi:10.1071/EA9780381

León-Mediavilla J, Senovilla M, Montiel J, Gil-Díez P, Saez Á, Kryvoruchko IS, Reguera M, Udvardi MK, Imperial J, González-Guerrero M (2018) Mtmtp2-facilitated zinc transport into intracellular compartments is essential for nodule development in Medicago truncatula. Frontiers in Plant Science 9, 990. doi:10.3389/fpls.2018.00990

Li GD, Helyar KR, Welham SJ, Conyers MK, Castleman LJC, Fisher RP, Evans CM, Cullis BR, Cregan PD (2006) Pasture and sheep responses to lime application in a grazing experiment in a high-rainfall area, southeastern Australia. I. Pasture production. Australian Journal of Agricultural Research 57, 1045-1055. doi:10.1071/AR05298

Li GD, Lodge GM, Moore GA, Craig AD, Dear BS, Boschma SP, Albertson TO, Miller SM, Harden S, Hayes RC, Hughes SJ, Snowball R, Smith AB, Cullis BR (2008) Evaluation of perennial pasture legumes and herbs to identify species with high herbage production and persistence in mixed farming zones in southern Australia. Australian Journal of Experimental Agriculture 48, 449-466. doi:10.1071/EA07108

Li GD, Conyers MK, Heylar KR, Lisle CJ, Poile GJ, Cullis BR (2019) Long-term surface application of lime ameliorates subsurface soil acidity in the mixed farming zone of south-eastern Australia. Geoderma 338, 236-246.

Lindström K, Murwira M, Willems A, Altier N (2010) The biodiversity of beneficial microbe-host mutualism: the case of rhizobia. Research in Microbiology 161, 453-463. doi:10.1016/j.resmic.2010.05.005 
Lines EW (1935) The effect of the ingestion of minute quantities of cobalt by sheep affected with "coast disease": A preliminary note. Journal. Council for Scientific and Industrial Research (Australia) 8, 117-119.

Liu GB, Kemp DR (1992) Water-Stress Affects the Productivity, Growth Components, Competitiveness and Water Relations of Phalaris and White Clover Growing in a Mixed Pasture. Australian Journal of Agricultural Research 43, 657-672.

Lowendorf HS (1980) Factors affecting survival of rhizobium in soil. In 'Advances in microbial ecology'. (Ed. M Alexander) pp. 87-124. (Springer: Boston, MA, USA)

Lu Y, Li YJ, Zhang JC, Xiao YT, Yue YS, Duan LS, Zhang MC, LiZH(2013) Overexpression of Arabidopsis molybdenum cofactor sulfurase gene confers drought tolerance in maize (Zea mays L.). PLoS One 8, E52126. doi:10.1371/journal.pone.0052126

15 Ludlow MM (1989) Strategies of response to water stress. In 'Structural and functional responses to environmental stresses: water shortage'. (Eds KH Kreeb, H Richter, TM Hinckley) pp. 269-281. (SPB Academic Publishing BV: The Hague)

Ma C, Burd S, Lers A (2015) miR408 is involved in abiotic stress responses in Arabidopsis. The Plant Journal 84, 169-187. doi:10.1111/tpj.12999

Mackay AD, Caradus JR, Dunlop J, Wewala GS, Mouat MCH, Lambert MG, Hart AL, Vandenbosch J (1990) Response to phosphorus of a world collection of white clover cultivars. Genetic Aspects of Plant Mineral Nutrition 42, 553-558. doi:10.1007/978-94-009-2053-8_76

25 Marschner H (2012) 'Marschner's mineral nutrition of higher plants (Academic Press: Waltham, MA, USA)

McInnes A, Haq K (2007) Contributions of Rhizobia to Soil Nitrogen Fertility. In 'Soil biological fertility: A key to sustainable land use in agriculture'. (Eds LK Abbott, DV Murphy) pp. 99-128. (Springer: Dordrecht, The Netherlands)

McInnes A, Thies JE, Abbott LK, Howieson JG (2004) Structure and diversity among rhizobial strains, populations and communities - a review. Soil Biology \& Biochemistry 36, 1295-1308 doi:10.1016/j. soilbio.2004.04.011

35 McLachlan KD (1955) Phosphorus, sulphur, and molybdenum deficiencies in soils from eastern Australia in relation to nutrient supply and some characteristics of soil and climate. Australian Journal of Agricultural Research 6, 673-684. doi:10.1071/AR9550673

McLachlan KD, De Marco DG (1968) The influence of gypsum particle size on pasture response on a sulphur deficient soil. Australian Journal of Experimental Agriculture 8, 203-209. doi:10.1071/EA9680203

McVittie BJ, Hayes RC, Li GD, Sandral GA, Gardner MJ, McCormick JI, Lowrie R, Tidd J, Poile GJ (2012) Screening potential new perennial pasture legumes for tolerance to aluminium and manganese toxicities. In 'Proceedings of the Australian Legume Symposium'. February 8-9, Melbourne. (Ed. C Harris) pp. 55-57. (Australian Grasslands Association)

Mengel KK E.A. (2001) 'Principles of plant nutrition.' (Springer: Netherlands)

50 Miller G, Suzuki N, Ciftci-Yilmaz S, Mittler R (2010) Reactive oxygen species homeostasis and signalling during drought and salinity stresses. Plant, Cell \& Environment 33, 453-467. doi:10.1111/j.1365-3040. 2009.02041.x

Mills A, Moot DJ, McKenzie BA (2006) Cocksfoot pasture production in relation to environmental variables. Proceedings of the New Zealand Grassland Association 68, 89-94.

Minasny B, McBratney AB (2018) Limited effect of organic matter on soil available water capacity. European Journal of Soil Science 69, 39-47. doi:10.1111/ejss. 12475

60 Monk S, Moot DJ, Belgrave B, Rolston MP, Caradus JR (2016) Availability of seed for the hill country adapted forage legumes. Hill Country Symposium. New Zealand Grassland Association, New Zealand Society of Animal Production, and New Zealand Grassland Trust. Grassland Research and Practice Series No. 16. Rotorua. pp. 267-268.
Mouat MCH, Nes P (1985) Soil water content affects the availability of phosphate. Proceedings of the New Zealand Grassland Association 46, $185-189$.

Murray LK (2012) Early development characteristics of different clover species during establishment. Lincoln University, New Zealand.

Nichols PGH, Revell CK, Humphries AW, Howie JH, Hall EJ, Sandral GA, Ghamkhar K, Harris CA (2012) Temperate pasture legumes in Australia their history, current use, and future prospects. Crop and Pasture Science 63, 691-725. doi:10.1071/CP12194

Nichols PGH, Foster KJ, Piano E, Pecetti L, Kaur P, Ghamkhar K, Collins WJ (2013) Genetic improvement of subterranean clover (Trifolium subterraneum L.). 1. Germplasm, traits and future prospects. Crop and Pasture Science 64, 312-346. doi:10.1071/CP13118

Nichols SN, Crush JR, Ouyang L (2014a) Phosphate responses of some Trifolium repens x T. uniflorum interspecific hybrids grown in soil. Crop and Pasture Science 65, 382-387. doi:10.1071/CP14029

Nichols SN, Hofmann RW, Williams WM (2014b) Drought resistance of Trifolium repens $x$ Trifolium uniflorum interspecific hybrids. Crop and Pasture Science 65, 911-921. doi:10.1071/CP14067

Nichols SN, Hofmann RW, Williams WM, van Koten C (2016) Rooting depth and root depth distribution of Trifolium repens $\mathrm{x}$ T. uniflorum interspecific hybrids. Annals of Botany 118, 699-710. doi:10.1093/aob/ mow067

Norton MR, FitzGerald RD (1993) Nationwide field testing of genotypes for white clover improvement. Australian Plant Introduction Review 24, $42-53$.

O'Hara GW (2001) Nutritional constraints on root nodule bacteria affecting symbiotic nitrogen fixation: a review. Australian Journal of Experimental Agriculture 41, 417-433. doi:10.1071/EA00087

O'Hara GW, Boonkerd N, Dilworth MJ (1988) Mineral constraints to nitrogen fixation. Plant and Soil 108, 93-110. doi:10.1007/BF02370104

Orgill SE, Condon JR, Conyers MK, Greene RSB, Morris SG, Murphy BW (2014) Sensitivity of soil carbon to management and environmental factors within Australian perennial pasture systems. Geoderma 214-215, 70-79. doi:10.1016/j.geoderma.2013.10.001

Osakabe Y, Osakabe K, Shinozaki K, Tran LSP (2014) Response of plants to water stress. Frontiers in Plant Science 5, 86.

Parker CA, Trinick MJ, Chatel DL (1977) Rhizobia as soil and rhizosphere inhabitants. In 'A treatise on dinitrogen fixation, section IV: agronomy and ecology'. (Eds R Hardy, AH Gibson) pp. 311-352. (John Wiley \& Sons: New York)

Pearson CJ, Brown R, Collins WJ, Archer KA, Wood MS, Petersen C, Bootle B (1997) An Australian temperate pastures database. Australian Journal of Agricultural Research 48, 453-466. doi:10.1071/A96095

Peoples MB, Brockwell J, Hunt JR, Swan AD, Watson L, Hayes RC, Li GD, Hackney B, Nuttall JG, Davies SL, Fillery IRP (2012) Factors affecting the potential contributions of $\mathrm{N}_{2}$ fixation by legumes in Australian pasture systems. Crop \& Pasture Science 63, 759-786. doi:10.1071/CP12123

Peterson JR (1987) Seed production as a factor in pasture cultivar adoption. In 'Temperate pastures: their production, use and management'. (Eds JL Wheeler, CJ Pearson, GE Robards) pp. 272-275. (CSIRO: Australia)

Peverill KI, Judson GJ (1999) Cobalt. In 'Soil analysis: an interpretation manual'. (Eds KI Peverill, DJ Reuter, LA Sparrow) (CSIRO Publishing: Melbourne)

Pinkerton A, Simpson JR (1986) Interactions of surface drying and subsurface nutrients affecting plant-growth on acidic soil profiles from an old pasture. Australian Journal of Experimental Agriculture 26, 681-689. doi:10.1071/EA9860681

Productivity Commission (2016) Intellectual Property Arrangements, Inquiry Report No. 78. Commonwealth of Australia, Canberra.

Real D, Sandral GA, Rebuffo M, Hughes SJ, Kelman WM, Mieres JM, Dods K, Crossa J (2012) Breeding of an early-flowering and drought-tolerant Lotus corniculatus L. variety for the high-rainfall zone of southern Australia. Crop \& Pasture Science 63, 848-857. doi:10.1071/CP12173

\section{5}


Redondo-Nieto M, Rivilla R, El-Hamdaoui A, Bonilla I, Bolaños L (2001) Research Note: Boron deficiency affects early infection events in the peaRhizobium symbiotic interaction. Functional Plant Biology 28, 819-823. doi:10.1071/PP01020

5 Reuter DJ, Dyson CB, Elliott DE, Lewis DC, Rudd CL (1995) An appraisal of soil phosphorus testing data for crops and pastures in South Australia. Australian Journal of Experimental Agriculture 35, 979-995. doi:10.1071/EA9950979

Richardson AE, Djordjevic MA, Rolfe BG, Simpson RJ(1989) Expression of nodulation genes in rhizobium and acid-sensitivity of nodule formation. Functional Plant Biology 16, 117-129. doi:10.1071/PP9890117

Roper MM (2005) Managing soils to enhance the potential for bioremediation of water repellency. Australian Journal of Soil Research 43, 803-810. doi:10.1071/SR05061

15 Roper MM, Davies SL, Blackwell PS, Hall DJM, Bakker DM, Jongepier R, Ward PR (2015) Management options for water-repellent soils in Australian dryland agriculture. Soil Research 53, 786-806. doi:10.1071/SR14330

Rowe BA, Johnson DE (1988) Residual effects of limestone on pasture yields, soil $\mathrm{pH}$ and soil aluminium in a krasnozem in north-western Tasmania. Australian Journal of Experimental Agriculture 28, 571-576. doi:10.1071/EA9880571

Rowe BA, Johnson DE (1989) Liming reduces the soil strength of a Krasnozem. In 'Proceedings of the 5th Australian Society of Agronomy Conference'. (Ed. GP Ayling) Available at: http://www. regional.org.au/au/asa/1989/contributed/plant-nutrition/p-42.htm.

Rowe BA, Johnson DE (1995) Residual benefits of limestone and superphosphate on barley yields and soil-water deficits on a krasnozem in north-western Tasmania. Australian Journal of Experimental Agriculture 35, 611-617. doi:10.1071/EA9950611

Ryan P (2018) Assessing the role of genetics for improving the potential yield of Australia's major grain crops on acid soils. Crop \& Pasture Science 69, 242-264. doi:10.1071/CP17310

Ryan PR, Ditomaso JM, Kochian LV (1993) Aluminium Toxicity in Roots: An Investigation of Spatial Sensitivity and the Role of the Root Cap. Journal of Experimental Botany 44, 437-446. doi:10.1093/jxb/44.2.437

Sanders JR (1983) The effect of $\mathrm{pH}$ on the total and free ionic concentrations of manganese, zinc and cobalt in soil solutions. Journal of Soil Science 34, 315-323. doi:10.1111/j.1365-2389.1983.tb01037.x

40 Sandral GA, Dear BS, Virgona JM, Swan AD, Orchard BA (2006) Changes in soil water content under annual- and perennial-based pasture systems in the wheatbelt of southern New South Wales. Australian Journal of Agricultural Research 57, 321-333. doi:10.1071/AR04017

Sandral GA, Price A, Hildebrand SM, Fuller CG, Haling RE, Stefanski A, Yang Z, Culvenor RA, Ryan MH, Kidd DR, Diffey S, Lambers H, Simpson RJ (2019) Field benchmarking of the critical external phosphorus requirements of pasture legumes for southern Australia. Crop \& Pasture Science 70, xxx.

Schlichting E, Sparrow LA (1988) Distribution and amelioration of Manganese toxic soils. In 'Manganese in Soils and Plants'. (Eds RD Graham, RJ Hannam, NC Uren) pp. 277-292. (Kluwer Academic Publishers: Dordrecht)

Seliga H (1998) Nitrogen fixation in several grain legume species with contrasting sensitivities to copper nutrition. Acta Physiologiae Plantarum 20, 263-267. doi:10.1007/s11738-998-0057-6

Shannon PW, Pringle RM, Mansell GP, Edmeades DC (1984) Effects of lime on pasture production on soils in the North Island of New Zealand. New Zealand Journal of Agricultural Research 27, 357-361. doi:10.1080/ 00288233.1984 .10430636

60 Shaw NH, Barrie N, Kipps EH (1944) The effect of CaO, phosphate and molybdenum on the growth of lucerne in Duntroon loam. Journal. Council for Scientific and Industrial Research (Australia) 17, 233-241.

Sillanpää M (1982) 'Micronutrients and the nutrient status of soils: a global study.' (FAO: Rome)
Siman A, Flemons K (1970) Goulburn lucerne failures linked with induced manganese toxicity. Agricultural Gazette of New South Wales 81, 662-663.

Simpson RJ, Richardson AE, Nichols SN, Crush JR (2014) Pasture plants and soil fertility management to improve the efficiency of phosphorus fertiliser use in temperate grassland systems. Crop \& Pasture Science 65, 556-575. doi:10.1071/CP13395

Simpson RJ, Stefanski A, Marshall DJ, Moore AD, Richardson AE (2015) Management of soil phosphorus fertility determines the phosphorus budget of a temperate grazing system and is the key to improving phosphorus efficiency. Agriculture, Ecosystems \& Environment 212, 263-277. doi:10.1016/j.agee.2015.06.026

Singh DK, Sale PWG (1997) Defoliation frequency and the response by white clover to increasing phosphorus supply 1 . Leaf dry matter yield and plant morphology responses. Australian Journal of Agricultural Research 48, 111-118. doi:10.1071/A96053

Singh DK, Sale PWG (1998) Phosphorus supply and the growth of frequently defoliated white clover (Trifolium repens L.) in dry soil. Plant and Soil 205, 155-162. doi:10.1023/A:1004316726665

Singh DK, Sale PWG (2000) Growth and potential conductivity of white clover roots in dry soil with increasing phosphorus supply and defoliation frequency. Agronomy Journal 92, 868-874. doi:10.2134/agronj2000. 925868x

Singh DK, Sale PWG, McKenzie BM (1997) Water relations of white clover (Trifolium repens L.) in a drying soil, as a function of phosphorus supply and defoliation frequency. Australian Journal of Agricultural Research 48, 675-682. doi:10.1071/A96156

Singh DK, Sale PWG, Gourley CJP, Hasthorpe C (1999) High phosphorus supply increases persistence and growth of white clover in grazed dairy pastures during dry summer conditions. Australian Journal of Experimental Agriculture 39, 579-585. doi:10.1071/EA98082

Singh DK, Sale PWG, Pallaghy CK, Singh V (2000) Role of proline and leaf expansion rate in the recovery of stressed white clover leaves with increased phosphorus concentration. New Phytologist 146, 261-269. doi:10.1046/j.1469-8137.2000.00643.x

Slattery J, Pearce D (2002) Development of Elite Inoculant Rhizobium Strains in Southeastern Australia. In 'Inoculants and nitrogen fixation of legumes in Vietnam, ACIAR Proceedings No. 109e'. (Ed. D Herridge) pp. 86-94. (ACIAR: Vietnam)

Slattery JF, Coventry DR, Slattery WJ (2001) Rhizobial ecology as affected by the soil environment. Australian Journal of Experimental Agriculture 41, 289-298. doi:10.1071/EA99159

Smith RS, Bishop DJ (1998) Register of Australian herbage plant cultivars. B. 1. Clover. B. Trifolium pratense L. (red clover) cv. Astred. Australian Journal of Experimental Agriculture 38, 319-320. doi:10.1071/ EA98035_CU

Smith A, Morrison ARJ (1983) A deep rooted white clover for South African conditions. Proceedings of the Annual Congresses of the Grassland Society of Southern Africa 18, 50-52. doi:10.1080/00725560. 1983.9648981

Snaydon RW, Bradshaw AD (1962) Differences between natural populations of Trifolium repens $\mathrm{L}$. in response to mineral nutrients. 1. Phosphate. Journal of Experimental Botany 13, 422-434. doi: 10.1093/jxb/13.3.422

Spencer K, Govaars AG (1982) 'The potassium status of pastures in the Moss Vale district, New South Wales. Technical Paper No. 38. Commonwealth of Australia Council for Scientific and Industrial Research Division of Plant Industry.

Steed GR, Reeves TG, Willatt ST (1987) Effects of deep ripping and liming on soil water deficits, sorptivity and penetrometer resistance. Australian Journal of Experimental Agriculture 27, 701-705. doi:10.1071/ EA9870701

Stevenson K, Zhou MX, Smith RW (2017) Screening for waterlogging tolerance in strawberry clover and other perennial legumes. In '18th Australian Society of Agronomy Conference, Doing More with Less'. 
Ballarat, Vic. (Eds GJ O'Leary, RD Armstrong, L Hafner) http://www. agronomyaustraliaproceedings.org/.

Taylor GB (2005) Hardseededness in Mediterranean annual pasture legumes in Australia: a review. Australian Journal of Agricultural Research 56, 645-661. doi:10.1071/AR04284

Thain RI (1955) Cobalt deficiency in sheep and cattle. Tasmanian Journal of Agriculture 26, 154-164.

Thies JE, Singleton PW, Bohlool BB (1991) Influence of the size of Indigenous rhizobial populations on establishment and symbiotic performance of introduced rhizobia on field-grown legumes. Applied and Environmental Microbiology 57, 19-28.

Thies JE, Woomer PL, Singleton PW (1995) Enrichment of Bradyrhizobium spp populations in soil due to cropping of the homologous host legume. Soil Biology \& Biochemistry 27, 633-636. doi:10.1016/0038-0717(95) 98643-3

Thomas RG (1987) Reproductive development. In 'White clover'. (Eds MJ Baker, WM Williams) pp. 63-123. (CAB International: Wallingford, UK)

Turner NC (1986) Adaptation to water deficits: a changing perspective. Australian Journal of Plant Physiology 13, 175-190.

Turner LB (1990) Water relations of white clover (Trifolium repens): Water potential gradients and plant morphology. Annals of Botany 65, 285-290. doi:10.1093/oxfordjournals.aob.a087936

Turner LB (1993) The Effect of Water-Stress on Floral Characters, Pollination and Seed Set in White Clover (Trifolium repens L). Journal of Experimental Botany 44, 1155-1160. doi:10.1093/jxb/ 44.7.1155

Unkovich MJ, Sanford P, Pate JS (1996) Nodulation and nitrogen fixation by subterranean clover in acid soils as influenced by lime application, toxic aluminium, soil mineral N, and competition from annual ryegrass. Soil Biology \& Biochemistry 28, 639-648. doi:10.1016/0038-0717(95) 00174-3

Vance CP (2008) Carbon and nitrogen metabolism in legume nodules. In 'Nitrogen-fixing leguminous symbioses'. (Eds MJ Dilworth, EK James, JI Sprent, WE Newton) (Springer Netherlands: Dordrecht, The Netherlands)

Virgona JM, Dear BS (1996) Comparative performance of Caucasion clover (Trifolium ambiguum cv. Monaro) after 11 years under low-input conditions in south-eastern Australia. New Zealand Journal of Agricultural Research 39, 245-253. doi:10.1080/00288233.1996. 9513183

Volaire F (2008) Plant traits and functional types to characterise drought survival of pluri-specific perennial herbaceous swards in Mediterranean areas. European Journal of Agronomy 29, 116-124. doi:10.1016/j. eja.2008.04.008

Waraich EA, Ahmad R, Yaseen Ashraf M, Saifullah, Ahmad M (2011) Improving agricultural water use efficiency by nutrient management in crop plants. Acta Agriculturce Scandinavica. Section B, Soil and Plant Science 61, 291-304. doi:10.1080/09064710.2010.491954
Ward PR, Dunin FX, Micin SF (2001) Water balance of annual and perennial pastures on a duplex soil in a Mediterranean environment. Australian Journal of Agricultural Research 52, 203-209. doi:10.1071/AR99081

Wheeler DM, Dodd MB (1995) Effect of aluminium on yield and plant 5 chemical concentrations of some temperate legumes. Plant and Soil 173, 133-145. doi:10.1007/BF00155525

Wheeler DM, O'Connor MB (1988) Why do pastures respond to lime? Proceedings of the New Zealand Grassland Association 60, 57-61.

White RE, Helyar KR, Ridley AM, Chen D, Heng LK, Evans J, Fisher R, 10 Hirth JR, Mele PM, Morrison GR, Cresswell HP, Paydar Z, Dunin FX, Dove H, Simpson RJ (2000) Soil factors affecting the sustainability and productivity of perennial and annual pastures in the high rainfall zone of south-eastern Australia. Australian Journal of Experimental Agriculture 40, 267-283. doi:10.1071/EA98013

Wigley K, Ridgway HJ, Humphries AW, Ballard RA, Moot DJ (2018) Increased lucerne nodulation in acid soils with Sinorhizobium meliloti and lucerne tolerant to low $\mathrm{pH}$ and high aluminium. Crop \& Pasture Science 69, 1031-1040. doi:10.1071/CP18124

Williams CH (1980) Soil acidification under clover pasture. Australian Journal of Experimental Agriculture and Animal Husbandry 20, 561-567. doi:10.1071/EA9800561

Williams WM (2014) Trifolium interspecific hybridisation: widening the white clover gene pool. Crop \& Pasture Science 65, 1091-1106. doi: $10.1071 / \mathrm{CP} 13294$

Wimmer MA, Eichert T (2013) Review: Mechanisms for boron deficiencymediated changes in plant water relations. Plant Science 203-204, 25-32. doi:10.1016/j.plantsci.2012.12.012

Wong MTF, Bell RW, Frost K (2005) Mapping boron deficiency risk in soils of south-west Western Australia using a weight of evidence model. Soil Research 43, 811-818. doi:10.1071/SR05022

Woodfield DR, Clifford PTP, Baird IJ, Cousins GR, Miller JE, Widdup KH, Caradus JR (2003) Grasslands tribute: a multi-purpose white clover for Australasia. Proceedings of the New Zealand Grassland Association 65, 157-162.

Wu SW, Hu CX, Tan QL, Nie ZJ, Sun XC (2014) Effects of molybdenum on water utilization, antioxidative defense system and osmotic-adjustment ability in winter wheat (Triticum aestivum) under drought stress. Plant Physiology and Biochemistry 83, 365-374. doi:10.1016/j.plaphy. 2014.08.022

Yang Z, Culvenor RA, Haling RE, Stefanski A, Ryan MH, Sandral GA, Kidd DR, Lambers H, Simpson RJ (2017) Variation in root traits associated with nutrient foraging among temperate pasture legumes and grasses. Grass and Forage Science 72, 93-103. doi:10.1111/gfs.12199

Yates RJ, Howieson JG, Real D, Reeve WG, Vivas-Marfisi A, O'Hara GW (2005) Evidence of selection for effective nodulation in the Trifolium spp. symbiosis with Rhizobium leguminosarum biovar trifolii. Australian Journal of Experimental Agriculture 45, 189-198. doi:10.1071/ EA03168

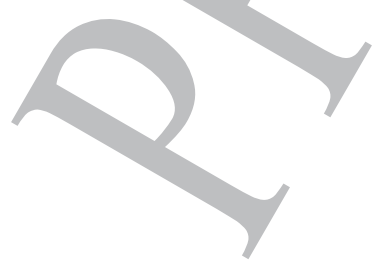




\section{AUTHOR QUERIES}

1. Reference "Dear, Peoples, Cocks, Swan, Smith, 1999" is not cited in the text. Please add an in-text citation or delete the reference.

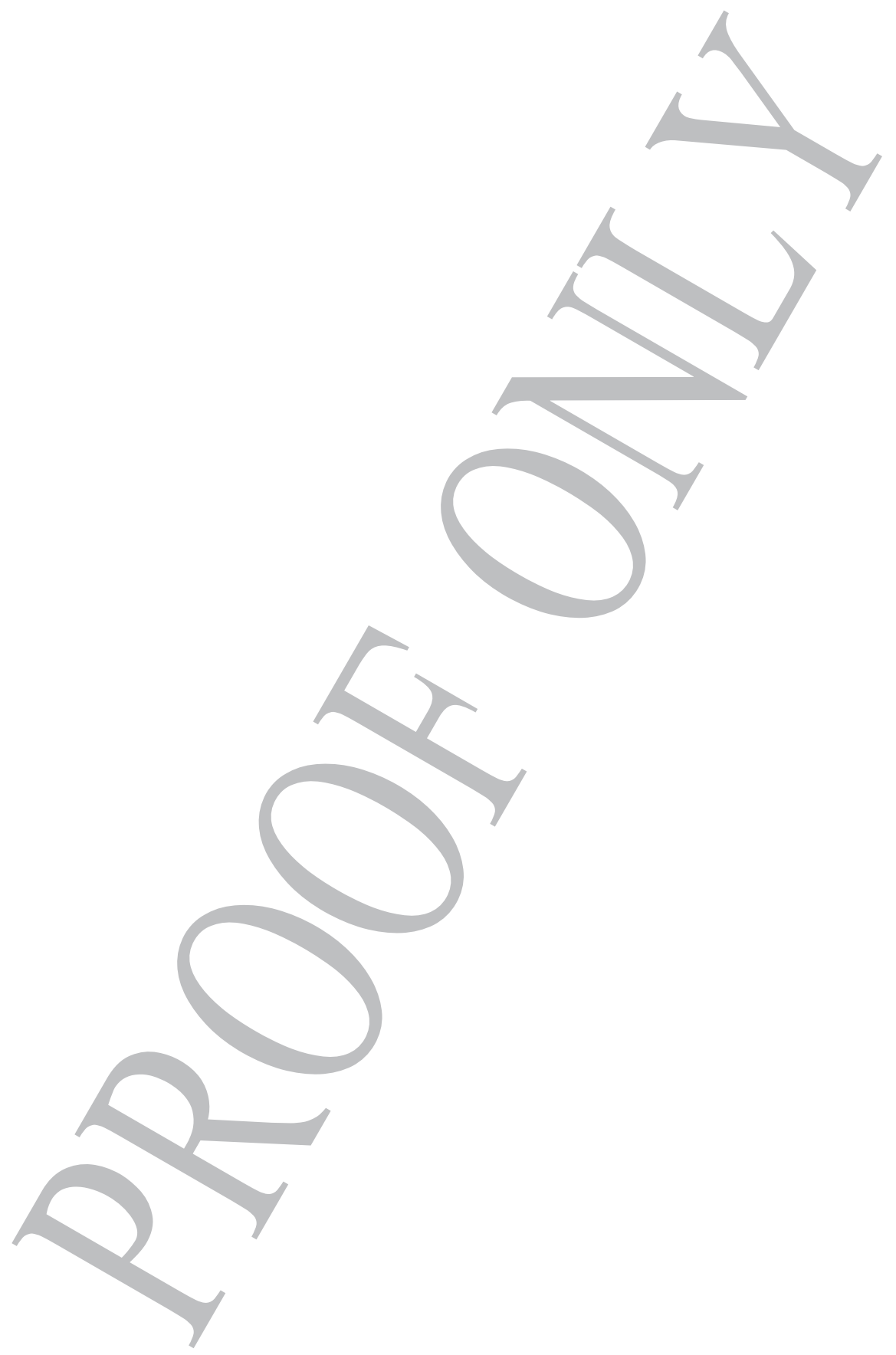

